\title{
EFFECT OF IRRIGATION INTERVALS, PHOSPHORUS LEVELS AND ANTIOXIDANTS OF FOLIAR ASCORBIC AND CITRIC ACID (ASCOBIN) APPLICATION ON MAIZE AND WHEAT CROPS AND SOME SOIL PROPERTIES \\ El-Maddah, E. I. ; M. El-D. El-Sodany and A. A. Mahmoud \\ Soil, Water and Environment Res. Inst. Agric. Res. Center, Giza, Egypt.
}

\begin{abstract}
Field experiments were carried out on clay soil at El-Gemmeiza Agricultural Research Station, El-Gharbia Governorate, during two consecutive growing seasons, summer season 2010 and winter season 2010/2011.

The experiment was designed using a randomized complete block design as split-split plot with three replicates to study the effect of three irrigation intervals with phosphorus application to soil and foliar spray of ascobin (ascorbic and citric acids) to plants on growth and yield of maize, wheat crops and some soil properties. Furthermore economical analysis was done by calculating the net income for every treatment.

The obtained results could be summarized as follows:-

1- Increasing irrigation intervals significantly increased values of soil bulk density and water use efficiency, while total soil porosity, hydraulic conductivity, soil moisture content just before harvesting and water consumption take the opposite direction during the two growing seasons.

2- Decreasing irrigation intervals significantly decreased soil $\mathrm{pH}$, electrical conductivity (EC), soluble cations and anions, total soluble salts (TSS) and sodium adsorption ratio (SAR) and significantly increased available nutrients $\mathrm{N}$, $\mathrm{P}, \mathrm{K}, \mathrm{Fe}, \mathrm{Mn}, \mathrm{Zn}$ and $\mathrm{Cu}$ in the soil.

3- Increasing phosphorus applications rate significantly increased water consumption, water use efficiency, yield and its components, electrical conductivity (EC), availability of macro and micronutrients of the soil and its concentrations and uptake in grains in both seasons.

4- Foliar application of ascobin significantly increased water consumption, water use efficiency, concentrations and uptake of macro and micronutrients $\mathrm{N}, \mathrm{P}, \mathrm{K}, \mathrm{Fe}$, $\mathrm{Mn}, \mathrm{Zn}$ and $\mathrm{Cu}$ of maize and wheat grains and yield and its components. While foliar application with ascobin had no effects on soil physical or chemical properties.

5- Cost benefit analysis revealed that the most valuable combination is irrigation every two weeks in the first season (maize plants) and every four weeks in the second one (wheat plants) at $100 \%$ of the recommended dose of phosphorus in both seasons with ascobin foliar application.

Keywords: Irrigation intervals, phosphorus levels and antioxidants foliar (ascorbic and citric acid)
\end{abstract}

\section{INTRODUCTION}

Water is the limiting factor of agriculture production in arid and semiarid regions. Also, it considered as an important element in the dynamics of plant and soil physical and chemical properties. Ghaly and El-Sodany (2009) found that three weeks irrigation intervals for Nigella sativa $L$ resulted in significant 
increases of total porosity, hydraulic conductivity, water consumption and soil moisture content just before harvesting as compared with 4 and 5 weeks irrigation intervals. Meanwhile, the values of soil bulk density, water use efficiency, soil pH and electrical conductivity take the opposite trend.

Mohamed et al., (1995) reported that the consumptive use of water increased as the available soil moisture increased, whereas water use efficiency increased under dry soil condition compare with wet condition. ElTawil (2003) found that the greatest seed and straw yield and the highest consumptive use of broad bean were obtained when irrigation every fifteen days. While, the highest water use efficiency was obtained with irrigation every thirty days coupled with $\mathrm{P}$ application for all soils under investigation. Ziadah et al., (2000) reported that irrigation intervals 15/15 days of cotton increased significantly water consumptive use, while it decreased significantly water use efficiency compared with the other tested irrigation treatments which were $30 / 15,15 / 30$ and $30 / 30$ days during vegetative and fruiting stages, respectively. Soomro et al., (2001) found that irrigation intervals on seed cotton yield at 14 days interval resulted in significant greater cotton yield as compared to 7 and 21 days intervals. They detected little increases in soil $\mathrm{pH}$ values, decreasing trend in ECe, ESP, and SAR was noted in the samples collected after harvest as compared to those collected before sowing.

Khamis (1987) showed that increasing soil moisture content caused a highly significant increase in concentration and uptake of NPK by broad bean seeds and shoots. El-Naggar et al., (1991) stated that concentration and uptake of micro elements in grain and straw of wheat increased as soil moisture stress decreased.

Refaat and Saleh (1997) studied the effect of irrigation intervals of 7, 14 or 28 days on sweet basil plant. They reported that the plant growth was reduced by increasing interval between irrigation treatments. Kandeel (2001) on Rosmarinus officinalis $L$. revealed that the irrigation intervals every 7 or 14 days significantly increased the plant height compared with irrigation every 21 days. The irrigation every 14 days significantly increased the (most cases) number of branches/plant, fresh weight of herb/plant, fresh weight of roots/plant and yearly yield of fresh and dry herb/plant as compared with the other two intervals.

Although phosphorus $(\mathrm{P})$ is an essential nutrient for crop production, but it does not occur as abundantly in soils as nitrogen $(\mathrm{N})$ and potassium $(\mathrm{K})$. Total $(\mathrm{P})$ in surface soils varies between about 0.005 and $0.15 \%$ (Havlin et al.,, 1999).

Nimje and Seth (1986) found that phosphorus application increased organic $\mathrm{C}$, total $(\mathrm{N})$ and available $(\mathrm{P})$ status of the soil. It is also improved bulk density and water-holding capacity of the soil. Sultani et al., (2007) found that phosphorus application showed meagre positive impact on various soil physical properties but did not significantly increased porosity or reduced bulk density. El-Sodany et al., (2009) found that the soil bulk density and consumptive water use were decreased, while total soil porosity, void ratio, settling percentage, pore size distribution, hydraulic conductivity, water use efficiency and yield quantity and quality were positively increased by 
application organic matter and inorganic phosphorus. El-Sodany and ElMaddah (2009) reported that the use of organic matter and inorganic phosphorus lead to a slightly decreases in soil $\mathrm{pH}$ and progressive increases in soil salinity (EC), soluble ions $\left(\mathrm{Ca}, \mathrm{Mg}, \mathrm{Na}, \mathrm{HCO}_{3}, \mathrm{Cl}\right.$ and $\left.\mathrm{SO}_{4}\right)$, total soluble salts (TSS) and sodium adsorption ratio (SAR).

Hanna et al., (1996) found that the consumptive use of water, water use efficiency and NPK concentration and its uptake in broad bean seeds and straw increased due to phosphorus application to soil. Barsoom (1998) showed that the dry matter weight and phosphorus uptake are increased by increasing the levels of phosphorus. Meanwhile, uptake of $\mathrm{Zn}$ and $\mathrm{Cu}$ increased at low phosphorus addition. Fouda et al., (2005) found that the concentration of heavy metals in the soil and dry matter production of alfalfa increased with application of phosphatic fertilizers. whereas, $\mathrm{Zn}, \mathrm{Mn}, \mathrm{Pb}$ and Cd uptake of alfalfa were reduced significantly.

Hussain et al., (2008) found a progressive increase in grain yield of wheat with the increment of $(P)$ from 60 to $120 \mathrm{~kg} \mathrm{ha}^{-1}$. Various crop traits such as number of fertile tillers, 1000-grain weight and number of grains per spike were significantly influenced by sowing dates and phosphorus application. Alias et al., (2003) in study of the effect of various levels of phosphorus on the yield and yield components of two maize cultivars, found that leaf area per plant, number of grains per cob and 1000- grains weight was significantly increased by increasing levels of $(P)$.

Ascobin as a foliar fertilizer, contains some activator hormones and organic acids as ascorbic and citric acids, had a promotion effect on growth and active constituents compounds on various plants such as fenugreek plant, (Mohamed and Naguib, 2002), Plantago species, (Ezz El-Din and Khalil, 2003) and on faba bean, maize and pea plants, (Ahmed, 1998).

Sheteawi (2007) found that ascobin increased salt tolerance by enhancing the accumulation of nontoxic metabolites (sugars, amino acids, proline and protein) and improving the levels of NPK. He reported that, ascobin spray could be adopted as a potential growth regulator or antioxidant to improve growth, yield and nutrient utilization particularly under moderate $\mathrm{NaCl}$ salinity levels on soybean. Abd El-Aziz et al., (2006) reported that all growth parameters of Khaya senegalensis (i.e. stem length, stem diameter, root length, leaves number/plant, leaf area and fresh and dry weight of all plant organs) and chemical constituents (i.e. the percentage and uptake of $\mathrm{N}, \mathrm{P}$ and $\mathrm{K}$ ) tended to increase by increasing the concentration of ascorbic acid up to $400 \mathrm{ppm}$ as compared to the untreated ones. El-Bassiouny et al., (2005) indicated that, foliar spray with ascorbic acid of antioxidants on faba bean plants significantly increased plant height, number of branches, pods and seeds/plant, seed yield(g)/plant, 100 seed weight as well as seed and straw yield (ton/fed). They added that, total carbohydrate, crude protein, $\mathrm{K}, \mathrm{P}$ and Ca contents in dry seeds were significantly increased. Talaat (2003) on sweet pepper detected that foliar application of ascorbic acid increased the content of macronutrients (N, P and K).

The present experiments were conducted to study the effect of irrigation intervals with phosphorus as soil application and foliar spray with 
ascobin (ascorbic and citric acids) on growth and yield of wheat and maize plants and some soil properties at El-Gharbia Governorate.

\section{MATERIALS AND METHODS}

Two successive field experiments were carried out at El-Gemmeiza Agricultural Research Station, El-Gharbia Governorate, for two seasons. Summer season 2010 using maize plants (Zea mays) and winter season 2010/2011 using wheat ( Triticum aestivum) plants to study the effect of irrigation intervals, phosphorus levels and antioxidants foliar (ascorbic and citric acid) application on plant characteristics and some soil properties under El-Gharbia Governorate conditions. Initial physical and chemical properties of the experimental soil are presented in Table (1).

The area of the experiment was divided into 72 plots, where each plot was $6 \mathrm{~m}^{2}$ (2 $\mathrm{m}$ in width and $3 \mathrm{~m}$ in length). A randomized complete block design as split-split plot with three replicates was used in both seasons.

Ascobin is consider as growth activator and plant nutrient which consists: $62 \%$ organic materials and ascorbic and $38 \%$ citric acids.

The three irrigation intervals were conducted as the main plots, the irrigation was executed every 1, 2 and 3 weeks during summer season 2010 and every 3,4 and 5 weeks during the winter season of 2010/2011.

Superphosphate $\left(15.5 \% \mathrm{P}_{2} \mathrm{O}_{5}\right)$ was added at the ratios of $0,50,75$ and $100 \%$ of the recommended dose of each crop as sub plots and applied to the surface soil before sowing in the first and second seasons. The recommended dose of $\mathrm{P}_{2} \mathrm{O}_{5}$ for maize crop $31 \mathrm{Kg} / \mathrm{fed}$ while it is $15.5 \mathrm{Kg} / \mathrm{fed}$ for wheat crop.

Table (1): The initial characteristics of the used soil.

\begin{tabular}{|c|c|c|c|c|}
\hline \multicolumn{2}{|c|}{ Soil depth, cm } & 0-30 & Soil depth, cm & 0-30 \\
\hline \multicolumn{5}{|c|}{ Soil physical properties } \\
\hline \multirow{3}{*}{$\begin{array}{c}\text { Particle size } \\
\text { distribution, } \\
\%\end{array}$} & Sand & 18.45 & Bulk density $\left(\mathrm{Db}, \mathrm{g} \mathrm{cm}^{-3}\right)$ & 1.19 \\
\hline & Silt & 34.05 & Total porosity (E, \%) & 55.00 \\
\hline & Clay & 47.50 & & \\
\hline \multicolumn{2}{|c|}{ Texture class } & Clayey & tydraulic conductivity (Kh, cm hr ') & 0.70 \\
\hline \multicolumn{5}{|c|}{ Soil chemical properties } \\
\hline \multicolumn{3}{|c|}{ Soluble ions, meq $\mathrm{I}^{-1}$} & Soil pH, 1:2.5 (suspension) & 7.74 \\
\hline $\mathrm{Ca}^{++}$ & & 8.80 & Soil EC, $\mathrm{dSm}^{-1}$ & 2.65 \\
\hline $\mathrm{Mg}^{++}$ & & 7.07 & TSS, $\%$ & 0.10 \\
\hline $\mathrm{Na}^{+}$ & & 10.17 & SAR & 3.61 \\
\hline $\mathrm{K}^{+}$ & & 0.35 & $\mathrm{CaCO}_{3}, \%$ & 4.29 \\
\hline $\mathrm{CO}_{3}{ }^{-\prime}$ & & 0.00 & Organic matter (O.M., \%) & 2.67 \\
\hline $\mathrm{HCO}_{3}{ }^{-}$ & & 4.94 & Organic carbon (O.C., \%) & 1.55 \\
\hline $\mathrm{CL}^{-}$ & & 12.50 & Total nitrogen (T.N., \%) & 0.155 \\
\hline $\mathrm{SO}_{4}$ & & 8.95 & C/N ratio & 10.01 \\
\hline \multicolumn{3}{|c|}{ DTPA- extractable micronutrients (ppm) } & Total P (T.P., \%) & 0.032 \\
\hline $\mathrm{Fe}$ & & 4.77 & Total K (T.K., \%) & 0.517 \\
\hline $\mathrm{Mn}$ & & 4.10 & Available $\mathrm{N}, \mathrm{mg} \mathrm{Kg}^{-1}$ & 35.15 \\
\hline $\mathrm{Zn}$ & & 4.86 & Available $\mathrm{P}, \mathrm{mg} \mathrm{Kg}^{-1}$ & 11.44 \\
\hline $\mathrm{Cu}$ & & 1.83 & Available $\mathrm{K}, \mathrm{mg} \mathrm{Kg}^{-1}$ & 382.45 \\
\hline
\end{tabular}


The sub-sub-plots were assigned to two foliar ascobin application: $\mathrm{S}_{0}$ : spraying $150 \mathrm{~L}$ water/fed. (control or without ascobin), $\mathrm{S}_{1}$ : two foliar spraying by ascobin at the rate of $200 \mathrm{~g} / 150 \mathrm{~L}$ water/fed in each spraying as follows: In the first season. The first spray was after thinning of maize plants and the second was three weeks after. While, in the second season, the first spray of ascobin was after one month of wheat sowing and the second was added one month later, as well as the control (untreated soil).

In summer season 2010, maize grains (Zea maize, three-way cross321) were planted at the rate of $15 \mathrm{~kg} / \mathrm{fed}$. during the first week of June 2010. while in winter season 2010/2011 wheat grains (Sakha 69) were planted at the rate of $60 \mathrm{Kg} / \mathrm{fed}$. during the third week of November 2010 .

During the two seasons, the basel doses of $\mathrm{N}$ and $\mathrm{K}$ were applied according to the recommendations dose for each crop in the form of ammonium nitrate $(33.5 \% \mathrm{~N})$ and potassium sulphate $\left(48 \% \mathrm{~K}_{2} \mathrm{O}\right)$. The other usual agricultural practices were carried out as usual for each crop according to the recommendations of El-Gemmeiza Research Station.

At harvesting of each growing season, soil samples $(0-30 \mathrm{~cm}$ depth) were collected from each plot. The collected soil samples were air-dried, ground and passed through $2 \mathrm{~mm}$ sieve and stored for chemical analysis.

Soil bulk density $\left(\mathrm{Db}, \mathrm{g} / \mathrm{cm}^{3}\right)$ was determined using the core methods (Vomocil, 1986). Total porosity (E, \%) was calculated using the following equations:-

$$
E, \%=\left(1-\frac{D b}{D r}\right) \times 100
$$

Where: $\mathrm{Db}=$ the bulk density, $\mathrm{g} / \mathrm{cm}^{3}$

$\mathrm{Dr}=$ the real density, taken as $2.65 \mathrm{~g} / \mathrm{cm}^{3}$

Hydraulic conductivity $(\mathrm{cm} / \mathrm{hr})$ was determined using undisturbed soil cores using a constant water head according to Richards (1954). Soil moisture content $(\Theta w, \%)$ were determined using the method outlined by Stakman (1969). Water consumption (CU) was determined by collecting soil samples from each plot before and after 48 hours of every irrigation and computed according to the Israelsen and Hansen's equation (1962)

Where:

$$
\text { Water consumption, } c m=\frac{\theta_{2}-\theta_{1}}{100} \times D b \times D
$$

$\theta_{2}=$ Soil moisture percentage on weight basis after 48 hours from irrigation.

$\theta_{1}=$ Soil moisture percentage before irrigation.

$\mathrm{Db}=$ Bulk density, $\quad \mathrm{g} / \mathrm{cm}^{3}$

$\mathrm{D}=$ Soil depth, $\quad \mathrm{cm}$

Water use efficiency (WUE) was calculated by dividing the yield crop $(\mathrm{kg} / \mathrm{fed}$.) by water consumptive use $(\mathrm{cm})$ according to Jensen's equation (1983):

$$
\text { WUE }, \mathrm{kg} \mathrm{fed}^{-1} \mathrm{~cm}^{-1}=\frac{\text { Grain yield },\left(\mathrm{kg} \mathrm{fed}^{-1}\right)}{\text { Water consumption }(\mathrm{cm})}
$$


Soil $\mathrm{pH}$ in soil water suspension (1:2.5) and soil electrical conductivity $\left(E C, \mathrm{dSm}^{-1}\right)$ in soil paste extract were measured. Soluble cations and anions were determined in soil paste extract using the methods described by Page et al., (1982).

Sodium Adsorption Ratio (SAR) was calculated as:

$$
\mathrm{SAR}=\frac{\mathrm{Na} \mathrm{meq} / \mathrm{I}}{\sqrt{\frac{\mathrm{Ca}+\mathrm{Mg} \mathrm{meq} / \mathrm{I}}{2}}}
$$

Total soluble salts, \% were calculated according to the following equation:

$$
\text { T.S.S., } \%=\frac{E C d S m^{-1} \times 0.064 \times S P}{100}
$$

where: $\mathrm{SP}=$ Saturation percentage

Total and available NPK of the soil were determined according to Hesse (1971). Total $\mathrm{N}$ by macro-Kjeldahel, total $\mathrm{P}$ by ascorbic acid molybdenum blue method and total $\mathrm{K}$ by flame photometer method.

Available $\mathrm{N}$ (extracted by $2 \mathrm{M} \mathrm{KCl}$ ) determined using the microkjeldahel method, available $\mathrm{P}$ (extracted by $0.5 \mathrm{~N} \mathrm{NaHCO}_{3}$ solution at $\mathrm{pH} 8.3$ ) determined using ascorbic acid method and available $\mathrm{K}$ (extracted by ammonium acetate solution at $\mathrm{pH}$ 7.0) was determined using a flame photometer.

The concentration of macronutrients in grain samples were determined according to Hesse (1971) and Cottenie (1980). Nitrogen was determined by Kjeldahel method, Phosphorus by Vanadomolybdate yellow method according to Jakson (1973) and Potassium by flame photometer method.

The concentration of micronutrients $(\mathrm{Fe}, \mathrm{Mn}, \mathrm{Zn}$ and $\mathrm{Cu}$ ) in soil and plant (grains) were determined by DTPA- method as described by Lindsay and Norvell (1978) measured by an Atomic Absorption Spectrophotometer (AAS).

At harvesting time of each crop, total yield of maize or wheat for each plot was separately harvested, and most of growth characters were recorded.

The collected data were statistically analyzed according to the procedure outlined by Snedecor and Cochran (1981).

Cost benefit analysis was done to compare between different treatments to state which treatment is more reliable. The test was executed according to the price of the yield (1500 LE/Ton) maize in the first season and (1500 LE/Ton) grain of wheat and (800 LE/Ton) straw of wheat in the second one, as well as the cost of different treatments was calculated considering conventional method of both fixed and variable costs. 


\section{RESULTS AND DISCUSSION}

\section{Effect of different treatments on some soil physical properties. \\ Soil bulk density (Db) and total porosity (E).}

Results in Tables (2 and 3 ) indicate that soil bulk density (Db) and total porosity (E) values were significantly changes for all different treatments at the end of the two seasons as compared with the control. The lowest values of $(\mathrm{Db})$ was recorded by added $100 \%$ of recommended dose of superphosphate with irrigation intervals every one week in the first season and every 3 weeks in the second one and without spraying ascobin, where the decrease were 10.08 and $11.02 \%$ in the first and second seasons, respectively, under the control. On the contrary, total porosity take the opposite direction where the highest values was recorded by the same treatment where the increases were 8.31 and $8.73 \%$ in the first and second seasons, respectively, compared with control.

Concerning irrigation intervals, the results show that the $(\mathrm{Db})$ values were significantly increased by increasing irrigation intervals, the values of $(\mathrm{Db})$ were differed between 1.12 and $1.23,1.09$ and $1.23 \mathrm{gm} / \mathrm{cm}^{3}$ in the first and second seasons for one and three weeks irrigation intervals in the first season and for three to five weeks in the second one, respectively. On the other hand, the values of (E) were significantly decreased by increasing irrigation intervals, differed between 57.83 and $53.54,58.75$ and $53.68 \%$ in the first and second seasons for the same irrigation intervals, respectively. Similar results were obtained by Ghaly and El-Sodany (2009), who reported that soil bulk density significantly decreased and total porosity significantly increased by irrigation intervals every three weeks for Nigella sativa $L$. as compared with 4 and 5 weeks.

Data in Tables (2 and 3) indicate that the values of $(\mathrm{Db})$ or $(\mathrm{E})$ were not significantly affected by superphosphate application. The same conclusion was obtained by Sultani et al., (2007), who found that phosphorus application did not significantly increased porosity or reduced bulk density.

Concerning spraying ascobin, data reveal that there is no wide variation between treatments for its effects on $(\mathrm{Db})$ or $(E)$ in the first and second seasons.

\section{Soil hydraulic conductivity $(\mathrm{Kh})$ and soil moisture content $(\Theta w)$ just before harvesting.}

Regarding the irrigation intervals, the results illustrated in Tables (2 and $3)$ show that the $(\mathrm{Kh})$ and $(\Theta \mathrm{w})$ values were significantly decreased with increasing irrigation intervals, the values of $(\mathrm{Kh})$ and $(\Theta \mathrm{w})$ were ranged from 0.81 to $0.61,0.85$ to $0.64 \mathrm{~cm} / \mathrm{hr}$ and 22.14 to $17.73,25.41$ to $20.23 \%$ in the first and second seasons, respectively. Similar results were obtained by Ghaly and El-Sodany (2009), who found that three weeks irrigation intervals for Nigella sativa L. resulted in a significantly increases of hydraulic conductivity and soil moisture content just before harvesting as compared with the other intervals.

However, results reveal that irrigation intervals every one or three weeks with the application of $100 \%$ of superphosphate of recommended 
El-Maddah, E. I. et al.

dose and spraying ascobin gave the highest values of $(\mathrm{Kh})$ and $(\Theta \mathrm{w}, \%)$ just before harvesting in the first and second seasons, respectively. The values were $0.84 \mathrm{~cm} / \mathrm{hr}, 22.74 \%$ and $0.87 \mathrm{~cm} / \mathrm{hr}, 26.11 \%$ for the first and second seasons.

Table (2): Effect of different treatments on soil physical properties in the first season

\begin{tabular}{|c|c|c|c|c|c|c|c|c|c|}
\hline 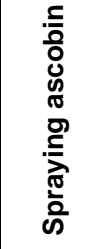 & 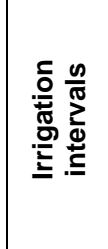 & 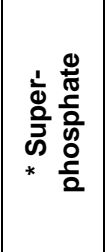 & 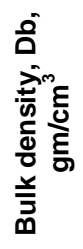 & $\begin{array}{l}\text { யే } \\
\frac{7}{0} \\
\frac{0}{0} \\
\frac{0}{\pi} \\
\frac{\pi}{0}\end{array}$ & 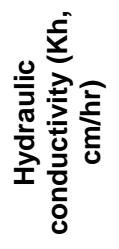 & 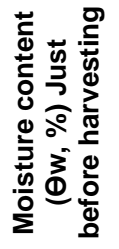 & 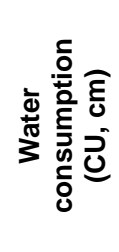 & 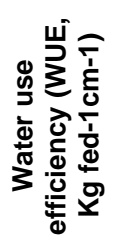 & 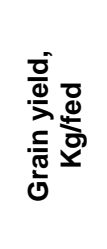 \\
\hline \multirow{12}{*}{ without } & \multirow{4}{*}{1 week } & 0 & 1.17 & 55.85 & 0.79 & 21.00 & 92.08 & 24.46 & 2252.20 \\
\hline & & 50 & 1.12 & 57.74 & 0.80 & 21.86 & 92.56 & 24.51 & 2268.90 \\
\hline & & 75 & 1.11 & 58.11 & 0.81 & 22.51 & 92.83 & 24.53 & 2277.50 \\
\hline & & 100 & 1.07 & 59.62 & 0.82 & 22.56 & 92.92 & 24.59 & 2284.60 \\
\hline & \multirow{4}{*}{2 weeks } & 0 & 1.19 & 55.00 & 0.70 & 19.26 & 89.74 & 25.42 & 2281.30 \\
\hline & & 50 & 1.18 & 55.51 & 0.71 & 19.44 & 90.05 & 26.11 & 2351.10 \\
\hline & & 75 & 1.17 & 55.91 & 0.72 & 19.70 & 90.44 & 26.88 & 2431.10 \\
\hline & & 100 & 1.16 & 56.15 & 0.75 & 19.90 & 91.21 & 27.49 & 2507.60 \\
\hline & \multirow{4}{*}{3 weeks } & 0 & 1.25 & 52.83 & 0.58 & 17.46 & 77.76 & 28.55 & 2220.00 \\
\hline & & 50 & 1.24 & 53.21 & 0.60 & 17.55 & 77.84 & 28.67 & 2231.60 \\
\hline & & 75 & 1.22 & 53.96 & 0.61 & 17.68 & 78.07 & 28.73 & 2242.80 \\
\hline & & 100 & 1.21 & 54.34 & 0.63 & 17.84 & 78.21 & 28.84 & 2255.40 \\
\hline \multirow{12}{*}{ with } & \multirow{4}{*}{1 week } & 0 & 1.15 & 56.60 & 0.79 & 21.83 & 92.28 & 28.33 & 2614.20 \\
\hline & & 50 & 1.12 & 57.74 & 0.80 & 22.01 & 92.63 & 28.75 & 2662.70 \\
\hline & & 75 & 1.11 & 58.11 & 0.81 & 22.61 & 92.95 & 29.31 & 2724.80 \\
\hline & & 100 & 1.09 & 58.87 & 0.84 & 22.74 & 93.44 & 30.48 & 2848.40 \\
\hline & \multirow{4}{*}{2 weeks } & 0 & 1.20 & 54.72 & 0.71 & 18.66 & 89.79 & 33.25 & 2985.40 \\
\hline & & 50 & 1.20 & 54.72 & 0.73 & 19.12 & 90.10 & 34.50 & 3108.40 \\
\hline & & 75 & 1.18 & 55.47 & 0.74 & 19.25 & 90.65 & 34.95 & 3167.80 \\
\hline & & 100 & 1.17 & 55.85 & 0.74 & 19.49 & 91.41 & 35.09 & 3207.70 \\
\hline & \multirow{4}{*}{3 weeks } & 0 & 1.25 & 52.83 & 0.60 & 17.48 & 77.82 & 32.38 & 2519.70 \\
\hline & & 50 & 1.24 & 53.21 & 0.62 & 17.80 & 77.88 & 32.40 & 2523.50 \\
\hline & & 75 & 1.22 & 53.96 & 0.63 & 17.93 & 78.72 & 32.50 & 2558.60 \\
\hline & & 100 & 1.22 & 53.96 & 0.64 & 18.10 & 79.15 & 32.77 & 2593.90 \\
\hline \multicolumn{3}{|c|}{ Control } & 1.19 & 55.05 & 0.70 & 19.26 & 89.74 & 25.42 & 2281.30 \\
\hline \multirow{4}{*}{\multicolumn{2}{|c|}{$\begin{array}{l}\text { (A) } \\
\text { Spraying } \\
\text { ascobin }\end{array}$}} & Without & 1.17 & 55.69 & 0.71 & 19.73 & 86.97 & 26.57 & 2300.34 \\
\hline & & with & 1.18 & 55.50 & 0.72 & 19.75 & 87.23 & 32.06 & 2792.93 \\
\hline & & $\mathrm{F}$ & NS & NS & NS & NS & $590.85^{*}$ & $586.29^{\star}$ & $585.88^{*}$ \\
\hline & & $\mathrm{LSD}_{05}$ & & & & & 0.05 & 0.84 & 87.57 \\
\hline \multirow{5}{*}{\multicolumn{2}{|c|}{$\begin{array}{l}\text { (B) } \\
\text { Irrigation } \\
\text { intervals }\end{array}$}} & 1 week & 1.12 & 57.83 & 0.81 & 22.14 & 92.71 & 26.87 & 2491.66 \\
\hline & & 2weeks & 1.18 & 55.42 & 0.72 & 19.35 & 90.42 & 30.46 & 2755.05 \\
\hline & & 3weeks & 1.23 & 53.54 & 0.61 & 17.73 & 78.18 & 30.61 & 2393.19 \\
\hline & & $\mathrm{F}$ & $9.09^{*}$ & $7.45^{*}$ & $69.93^{*}$ & $49.55^{*}$ & $1166.81^{*}$ & $919.37^{*}$ & $893.90^{*}$ \\
\hline & & LSD $_{05}$ & 0.06 & 2.57 & 0.04 & 1.03 & 0.75 & 0.30 & 20.41 \\
\hline \multirow{6}{*}{\multicolumn{2}{|c|}{$\begin{array}{l}\text { (C) } \\
\text { Supper } \\
\text { Phosphate }\end{array}$}} & 0 & 1.20 & 54.64 & 0.70 & 19.28 & 86.58 & 28.73 & 2478.80 \\
\hline & & 50 & 1.18 & 55.35 & 0.71 & 19.63 & 86.84 & 29.16 & 2524.37 \\
\hline & & 75 & 1.17 & 55.92 & 0.72 & 19.95 & 87.28 & 29.48 & 2567.10 \\
\hline & & 100 & 1.15 & 56.46 & 0.74 & 20.11 & 87.72 & 29.88 & 2616.27 \\
\hline & & $\mathrm{F}$ & NS & NS & NS & NS & $4.29^{*}$ & $36.43^{*}$ & $72.04^{*}$ \\
\hline & & LSD $_{05}$ & & & & & 0.70 & 0.25 & 19.90 \\
\hline
\end{tabular}


Concerning increasing superphosphate application, the results revealed that the values of $(\mathrm{Kh})$ and $(\Theta \mathrm{w})$ were insignificant. The values were differed between 0.70 and $0.74,0.72$ and $0.77 \mathrm{~cm} / \mathrm{hr}$ and between 19.28 and $20.11,22.19$ and $23.14 \%$ in the first and second seasons, respectively.

\section{Water consumption (CU) and water use efficiency (WUE).}

The results in Tables (2 and 3 ) show that the lowest values of (CU) were obtained by irrigation intervals every three weeks in the first season and five weeks in the second one without both spraying ascobin or phosphorus addition, where the values decreased by 13.36 and $11.42 \%$ in the first and second seasons, respectively as compared with control. While, the highest values of $(\mathrm{CU})$ were recorded with irrigation intervals every one week in the first season and three weeks in the second one with spraying ascobin and added $100 \%$ of recommended dose of phosphorus, where the values increased by 4.12 and $16.33 \%$ in the first and second seasons, respectively.

Concerning the irrigation intervals, the results clear that $(\mathrm{CU})$ for maize and wheat plants were significantly decreased by increasing irrigation intervals from one to three weeks and three to five weeks in the first and second seasons, where the values of $(\mathrm{CU})$ decreased from 92.71 to 78.18 and 87.97 to $67.95 \mathrm{~cm}$, respectively. Similar results were obtained by El-Tawil (2003), Ziadah et al., (2000) and Mohamed et al., (1995), they reported that the consumptive use of water increased as the available soil moisture increased, whereas water use efficiency increased under dry soil condition compare with wet condition.

Moreover, data of tables (2 and 3 ) reveal that $(\mathrm{CU})$ values for maize and wheat plants were significantly increased by increasing phosphorus application in the first and second seasons, the increases differed from 86.58 to 87.72 and 77.26 to $78.29 \mathrm{~cm}$, respectively. Similar results were obtained by Hanna et al., (1996), who found that the consumptive use of water and water use efficiency in broad bean increased due to phosphorus application to soil.

With regard to ascobin foliar, the results in Tables (2 and 3 ) indicate that $(\mathrm{CU})$ values for maize and wheat plants were significantly increased with ascobin foliar in the first and second seasons, where the values of (CU) were increased from 86.97 to $87.23,77.52$ to $77.96 \mathrm{~cm}$ for maize and wheat plants, respectively.

On the other hand, data in Tables (2 and 3 ) show that (WUE) values for maize and wheat plants take the opposite trend of (CU), where the (WUE) values were significantly changes with all different treatments. The highest (WUE) value was recorded by irrigation intervals every two or four weeks in the first and second seasons with $100 \%$ of phosphorus application levels and spraying ascobin, the increases were 38.05 and $36.78 \%$ in the first and second seasons, respectively as compared with control. 
El-Maddah, E. l. et al.

Table (3): Effect of different treatments on soil physical properties in the second season

\begin{tabular}{|c|c|c|c|c|c|c|c|c|c|}
\hline 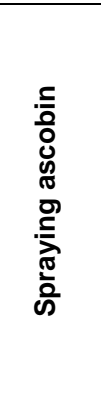 & 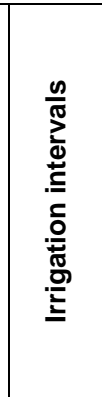 & $\begin{array}{l}\frac{0}{0} \\
\frac{0}{0} \\
\frac{0}{0} \\
0 \\
0 \\
\frac{1}{0} \\
\frac{1}{1} \\
\frac{1}{0} \\
\frac{0}{3} \\
\text { 心 } \\
\text { * }\end{array}$ & 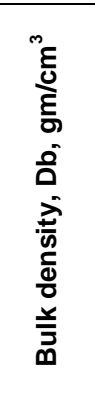 & 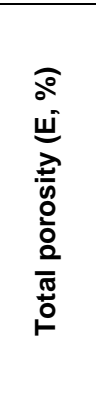 & 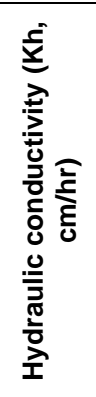 & 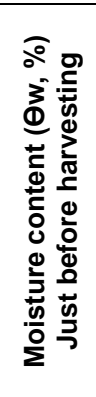 & 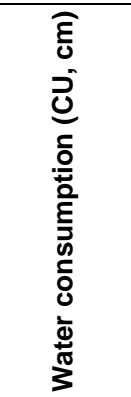 & 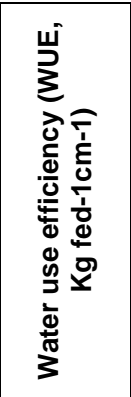 & 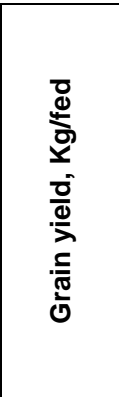 \\
\hline \multirow{12}{*}{ without } & \multirow{4}{*}{3 week } & 0 & 1.12 & 57.74 & 0.82 & 24.42 & 87.52 & 28.20 & 2468.13 \\
\hline & & 50 & 1.11 & 57.97 & 0.84 & 24.93 & 87.65 & 28.21 & 2472.80 \\
\hline & & 75 & 1.07 & 59.62 & 0.86 & 25.70 & 87.85 & 28.22 & 2479.33 \\
\hline & & 100 & 1.05 & 60.38 & 0.86 & 25.73 & 88.01 & 28.23 & 2484.40 \\
\hline & \multirow{4}{*}{$\begin{array}{c}4 \\
\text { weeks }\end{array}$} & 0 & 1.18 & 55.53 & 0.73 & 22.15 & 76.22 & 32.03 & \begin{tabular}{|l|}
2441.52 \\
\end{tabular} \\
\hline & & 50 & 1.17 & 55.85 & 0.74 & 22.39 & 76.67 & 32.69 & 2505.97 \\
\hline & & 75 & 1.16 & 56.23 & 0.75 & 22.65 & 77.54 & 33.15 & \begin{tabular}{|l|}
2570.67 \\
\end{tabular} \\
\hline & & 100 & 1.15 & 56.60 & 0.76 & 22.82 & 78.09 & 33.29 & \begin{tabular}{|l|}
2599.82 \\
\end{tabular} \\
\hline & \multirow{4}{*}{$\begin{array}{c}5 \\
\text { weeks }\end{array}$} & 0 & 1.24 & 53.21 & 0.58 & 19.73 & 67.51 & 36.05 & \begin{tabular}{|l|}
2433.99 \\
\end{tabular} \\
\hline & & 50 & 1.23 & 53.58 & 0.63 & 20.06 & 67.61 & 36.08 & 2439.11 \\
\hline & & 75 & 1.22 & 53.96 & 0.65 & 20.75 & 67.74 & 36.15 & 2448.56 \\
\hline & & 100 & 1.21 & 54.34 & 0.67 & 20.94 & 67.86 & 36.24 & 2459.14 \\
\hline \multirow{12}{*}{ with } & \multirow{4}{*}{3 week } & 0 & 1.13 & 57.18 & 0.83 & 25.18 & 87.74 & 33.57 & 2944.87 \\
\hline & & 50 & 1.11 & 58.29 & 0.83 & 25.20 & 88.00 & 34.11 & \begin{tabular}{|l|}
3001.34 \\
\end{tabular} \\
\hline & & 75 & 1.09 & 58.77 & 0.86 & 25.99 & 88.32 & 34.84 & 3076.60 \\
\hline & & 100 & 1.06 & 60.03 & 0.87 & 26.11 & 88.66 & 35.85 & 3178.31 \\
\hline & \multirow{4}{*}{$\begin{array}{c}4 \\
\text { weeks }\end{array}$} & 0 & 1.19 & 55.09 & 0.72 & 21.89 & 76.94 & 42.16 & 3244.03 \\
\hline & & 50 & 1.19 & 55.09 & 0.75 & 22.38 & 76.89 & 43.01 & 3306.48 \\
\hline & & 75 & 1.18 & 55.47 & 0.76 & 22.48 & 77.80 & 43.25 & 3364.90 \\
\hline & & 100 & 1.17 & 55.85 & 0.77 & 22.75 & 78.30 & 43.82 & 3430.67 \\
\hline & \multirow{4}{*}{$\begin{array}{c}5 \\
\text { weeks }\end{array}$} & 0 & 1.25 & 52.83 & 0.63 & 19.78 & 67.64 & 40.06 & 2709.49 \\
\hline & & 50 & 1.24 & 53.21 & 0.64 & 19.99 & 67.90 & 41.07 & 2788.92 \\
\hline & & 75 & 1.22 & 53.96 & 0.66 & 20.14 & 68.53 & 41.56 & 2848.54 \\
\hline & & 100 & 1.21 & 54.34 & 0.67 & 20.48 & 68.84 & 42.14 & 2901.25 \\
\hline \multicolumn{3}{|c|}{ Control } & 1.18 & 55.53 & 0.73 & 22.15 & 76.22 & 32.03 & 2441.52 \\
\hline \multirow{4}{*}{\multicolumn{2}{|c|}{$\begin{array}{c}\text { (A) } \\
\text { Spraying } \\
\text { ascobin }\end{array}$}} & Without & 1.16 & 56.25 & 0.74 & 22.69 & 77.52 & 32.38 & 2483.62 \\
\hline & & with & 1.17 & 55.84 & 0.75 & 22.70 & 77.96 & 39.62 & 3066.28 \\
\hline & & $\mathrm{F}$ & NS & NS & NS & NS & $612.31^{*}$ & $3423.31^{*}$ & $587.07^{*}$ \\
\hline & & $\mathrm{LSD}_{05}$ & & & & & 0.08 & 0.53 & \begin{tabular}{|l|}
103.48 \\
\end{tabular} \\
\hline \multirow{5}{*}{\multicolumn{2}{|c|}{$\begin{array}{c}(\mathrm{B}) \\
\text { Irrigation } \\
\text { intervals }\end{array}$}} & 3weeks & 1.09 & 58.75 & 0.85 & 25.41 & 87.97 & 31.40 & 2763.22 \\
\hline & & 4 eeks & 1.17 & 55.71 & 0.75 & 22.44 & 77.30 & 37.93 & 2933.01 \\
\hline & & 5weeks & 1.23 & 53.68 & 0.64 & 20.23 & 67.95 & 38.67 & 2628.62 \\
\hline & & $\mathrm{F}$ & $12.77^{*}$ & $10.16^{*}$ & $68.75^{\star}$ & $52.35^{\star}$ & $1167.38^{*}$ & $6115.97^{*}$ & 767.23* \\
\hline & & $\mathrm{LSD}_{05}$ & 0.06 & 2.61 & 0.04 & 1.17 & 0.96 & 0.17 & 17.96 \\
\hline \multirow{6}{*}{\multicolumn{2}{|c|}{$\begin{array}{c}\text { (C) } \\
\text { Supper } \\
\text { Phosphate }\end{array}$}} & 0 & 1.19 & 55.26 & 0.72 & 22.19 & 77.26 & 35.35 & 2707.00 \\
\hline & & 50 & 1.17 & 55.67 & 0.74 & 22.49 & 77.45 & 35.86 & 2752.44 \\
\hline & & 75 & 1.16 & 56.34 & 0.76 & 22.95 & 77.96 & 36.20 & \begin{tabular}{|l|}
2798.10 \\
\end{tabular} \\
\hline & & 100 & 1.14 & 56.92 & 0.77 & 23.14 & 78.29 & 36.59 & 2842.26 \\
\hline & & $\mathrm{F}$ & NS & NS & NS & NS & $4.74^{*}$ & $60.13^{*}$ & \begin{tabular}{|l}
$59.51^{*}$ \\
\end{tabular} \\
\hline & & $\mathrm{LSD}_{05}$ & & & & & 0.62 & 0.20 & 21.70 \\
\hline
\end{tabular}


Regarding irrigation intervals, the results reveal that the (WUE) values were significantly increase with increasing irrigation intervals from one to three weeks for maize plant and three to five weeks for wheat, the increases were from 26.87 to 30.61 and 31.40 to $38.67 \mathrm{~kg} \mathrm{fed}^{-1} \mathrm{~cm}^{-1}$ in the first and second seasons, respectively. Meanwhile, increasing phosphorus fertilizers to the recommended dose gave the highest values of (WUE), which were 29.88 and $36.59 \mathrm{~kg} \mathrm{fed}^{-1} \mathrm{~cm}^{-1}$ for maize and wheat plants, respectively. Thus, it is obvious that water use efficiency tended to decrease in water retained in the root zone. Similar conclusion was obtained by Hanna et al., (1996).

Concerning spraying ascobin, it can be noticed that (WUE) values were significantly increased with spraying ascobin, where the of (WUE) increased from 26.57 to $32.06,32.38$ to $39.62 \mathrm{~kg} \mathrm{fed}^{-1} \mathrm{~cm}^{-1}$ in the first and second seasons, respectively.

\section{Effect of different treatments on some soil chemical properties.} Soil $\mathrm{pH}$.

Data in Tables (4 and 5) show that all different treatments led to insignificant variation between soil $\mathrm{pH}$ values. The maximum value of soil $\mathrm{pH}$ was $7.60,7.55$ in the first and second seasons, which decreased by 1.81 , $1.82 \%$, respectively, compared with control. This value was obtained by irrigation intervals every one or three weeks in the first and second seasons with $100 \%$ of phosphorus application level for each season and spraying ascobin. On the contrary, the highest $\mathrm{pH}$ values were $7.83,7.80$, which increased by $1.16,1.43 \%$ of the two seasons, respectively, which obtained by irrigation intervals every three or five weeks in the first and second seasons without superphosphate addition and or spraying ascobin.

Concerning irrigation intervals, data reveal that soil $\mathrm{pH}$ values were significantly increased with increasing irrigation intervals. The increases of soil $\mathrm{pH}$ values were ranged from 7.63 to 7.81 by increasing irrigation intervals from one to three weeks in the first season, while in the second season were ranged from 7.57 to 7.78 by increasing irrigation intervals from three to five weeks. Similar results were obtained by Soomro et al., (2001), who found a little increase in soil $\mathrm{pH}$ values by irrigation intervals on seed cotton yield at 14 days compared to 7 and 21 day intervals.

Data in Tables (4 and 5) indicate that increasing level of phosphorus application to the recommended dose for maize and wheat plants, caused a decrease in soil $\mathrm{pH}$ value reached to 7.70 and 7.66 in the first and second seasons, respectively. Similar results were obtained by El-Sodany and ElMaddah (2009), they reported that soil $(\mathrm{pH})$ slightly decrease by using inorganic phosphorus.

It can be noticed from these tables that soil $\mathrm{pH}$ values were insignificantly affected by ascobin foliar for the two seasons, where its no wide variation with or without spraying ascobin.

Soil salinity

Data in Tables (4 and 5) show the values of electrical conductivity of soil paste extract $\left(\mathrm{EC}, \mathrm{dSm}^{-1}\right)$, soluble cations and anions (meq/l), total soluble salts (TSS, \%) and sodium adsorption ratio (SAR) of the soil as affected by different treatments. 
El-Maddah, E. I. et al.

4 
J. Soil Sci. and Agric. Eng., Mansoura Univ., Vol. 3 (1), January, 2012 5 
The results declear that all different treatments led to changes in these characters, where the minimum values of (EC), $\left(\mathrm{Ca}^{+2}, \mathrm{Mg}^{+2}, \mathrm{Na}^{+}, \mathrm{K}^{+}, \mathrm{Cl}^{-}\right.$and $\mathrm{SO}_{4}{ }^{-2}$ ), (TSS) and (SAR) were recorded by decreasing both irrigation intervals and phosphorus addition rates, as well as spraying ascobin. While the maximum values of these characters were recorded by increasing both irrigation intervals to be three and five weeks in the first and second seasons, respectively with increasing phosphorus levels to $100 \%$ of the recommended dose and without spraying ascobin.

Regarding the irrigation intervals, the results show that the values of (EC), $\left(\mathrm{Ca}^{+2}, \mathrm{Mg}^{+2}, \mathrm{Na}^{+}, \mathrm{K}^{+}, \mathrm{Cl}^{-}\right.$and $\left.\mathrm{SO}_{4}^{-2}\right)$, (TSS) and (SAR) were increased by increasing irrigation intervals from one to three weeks in the first season and from three to five weeks in the second one, this may be due to the lowest of irrigation intervals led to an increase in the leaching of soluble salts and decrease them at the two seasons. The values decreased to $(2.54$ and 2.42 $\left.\mathrm{dSm}^{-1}\right),(8.81$ and $8.23,6.98$ and $7.10,9.22$ and $8.69,0.35$ and $0.27,11.53$ and $11.48,9.01$ and $7.93 \mathrm{meq} / \mathrm{l}),(0.10$ and $0.10 \%)$ and (3.28 and 3.14$)$ with irrigation intervals every one or three weeks in the first and second seasons, respectively, and its reached to $\left(2.85\right.$ and $\left.2.76 \mathrm{dSm}^{-1}\right),(8.99$ and $8.66,7.32$ and $7.74,11.64$ and 10.87, 0.39 and $0.31,13.51$ and 13.42, 10.79 and 9.78 meq/l), $(0.13$ and $0.12 \%)$ and (4.08 and 3.80$)$ for the same characters with increasing irrigation intervals to be every three or five weeks in the first and second seasons, respectively. Similar conclusion was obtained by Soomro et al., (2001).

Also, it can be noticed from these tables that the values of (EC), (TSS) and (SAR) were significantly increased with increasing phosphorus levels from zero to $100 \%$ of the recommended dose, the increases differed from 2.63 to 2.75 and 2.53 to $2.65 \mathrm{dSm}^{-1}$ for (EC), 0.10 to 0.13 and 0.09 to $0.13 \%$ for (TSS) and 3.61 to 3.76 and 3.38 to 3.58 for (SAR) in the first and second seasons, respectively. Similar results were obtained by El-Sodany and ElMaddah (2009), they reported that soil salinity (EC), soluble ions, total soluble salts (TSS) and sodium adsorption ratio (SAR) were progressive increases by using inorganic phosphorus.

Concerning spraying ascobin, the results reveal that there is no significant variation of EC, TSS and SAR as a result of ascobin foliar application.

\section{Effect of different treatments on macro and micronutrients of the soil. Soil macronutrients.}

Data in Tables (6 and 7) indicate that the available N,P and $\mathrm{K}$ of the soil were changed with all different treatments at the end of the two growing seasons compared with control. The highest values of available $\mathrm{N}, \mathrm{P}$ and $\mathrm{K}$ were obtained by irrigation intervals every one week in the first season and three weeks in the second one with $100 \%$ recommended dose of phosphorus and spraying ascobin, where they increased by 20.97 and 21.20 $\%, 20.98$ and $22.40 \%$ and 23.73 and $26.76 \%$ for available N, P and $\mathrm{K}$ in the first and second seasons, respectively compared with control. While, the lowest values were detected with increasing irrigation intervals to become every three or five weeks in the first and second seasons respectively without addition of both phosphorus and spraying ascobin. 
Table (6):Effect of different treatments on soil macro and micronutrients in the first season

\begin{tabular}{|c|c|c|c|c|c|c|c|c|c|}
\hline \multirow{2}{*}{ 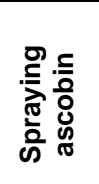 } & \multirow{2}{*}{ 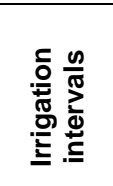 } & \multirow{2}{*}{ 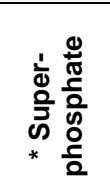 } & \multicolumn{3}{|c|}{\begin{tabular}{|c|} 
Available macronutrients \\
$(\mathrm{ppm})$
\end{tabular}} & \multicolumn{4}{|c|}{$\begin{array}{l}\text { DTPA- extractable micronutrients } \\
(\mathrm{ppm})\end{array}$} \\
\hline & & & $\mathbf{N}$ & $\mathbf{P}$ & $\mathbf{K}$ & $\mathrm{Fe}$ & Mn & $\mathrm{Zn}$ & $\mathrm{Cu}$ \\
\hline \multirow{12}{*}{ without } & \multirow{4}{*}{1 week } & 0 & 39.92 & 13.23 & 452.36 & 5.50 & 5.40 & 5.34 & 2.08 \\
\hline & & 50 & 40.50 & 13.43 & 459.63 & 5.62 & 5.48 & 5.38 & 2.11 \\
\hline & & 75 & 41.08 & 13.62 & 467.45 & 5.66 & 5.59 & 5.44 & 2.14 \\
\hline & & 100 & 41.65 & 13.82 & 474.59 & 5.79 & 5.64 & 5.51 & 2.15 \\
\hline & \multirow{4}{*}{2 weeks } & 0 & 35.15 & 11.44 & 382.45 & 4.77 & 4.10 & 4.86 & 1.83 \\
\hline & & 50 & 35.60 & 11.64 & 390.54 & 4.92 & 4.29 & 4.93 & 1.88 \\
\hline & & 75 & 36.06 & 11.82 & 397.00 & 5.04 & 4.48 & 5.04 & 1.93 \\
\hline & & 100 & 36.75 & 12.03 & 404.12 & 5.15 & 4.64 & 5.13 & 1.96 \\
\hline & \multirow{4}{*}{3 weeks } & 0 & 31.01 & 9.66 & 313.90 & 3.21 & 3.07 & 4.21 & 1.56 \\
\hline & & 50 & 31.24 & 9.86 & 322.00 & 3.54 & 3.14 & 4.34 & 1.64 \\
\hline & & 75 & 31.71 & 10.09 & 329.65 & 3.73 & 3.39 & 4.43 & 1.68 \\
\hline & & 100 & 32.17 & 10.28 & 337.84 & 3.92 & 3.59 & 4.50 & 1.70 \\
\hline \multirow{12}{*}{ with } & \multirow{4}{*}{1 week } & 0 & 40.35 & 13.25 & 450.70 & 5.30 & 5.46 & 5.29 & 2.06 \\
\hline & & 50 & 40.82 & 13.46 & 457.05 & 5.41 & 5.54 & 5.33 & 2.09 \\
\hline & & 75 & 41.62 & 13.68 & 465.16 & 5.52 & 5.58 & 5.38 & 2.10 \\
\hline & & 100 & 42.52 & 13.84 & 473.21 & 5.96 & 5.65 & 5.64 & 2.27 \\
\hline & \multirow{4}{*}{2 weeks } & 0 & 35.36 & 11.45 & 380.21 & 4.69 & 4.16 & 4.93 & 1.88 \\
\hline & & 50 & 35.81 & 11.64 & 390.72 & 4.85 & 4.34 & 4.95 & 1.90 \\
\hline & & 75 & 36.24 & 11.83 & 398.41 & 4.87 & 4.51 & 4.98 & 1.93 \\
\hline & & 100 & 36.97 & 12.11 & 406.09 & 4.90 & 4.69 & 5.04 & 1.95 \\
\hline & \multirow{4}{*}{3 weeks } & 0 & 31.83 & 9.71 & 314.59 & 3.66 & 3.08 & 4.34 & 1.61 \\
\hline & & 50 & 32.06 & 9.88 & 320.25 & 3.86 & 3.23 & 4.38 & 1.63 \\
\hline & & 75 & 32.29 & 10.06 & 325.56 & 3.99 & 3.35 & 4.46 & 1.68 \\
\hline & & 100 & 32.75 & 10.27 & 337.21 & 4.09 & 3.45 & 4.53 & 1.69 \\
\hline \multicolumn{3}{|c|}{ Control } & 35.15 & 11.44 & 382.45 & 4.77 & 4.10 & 4.86 & 1.83 \\
\hline \multirow{4}{*}{\multicolumn{2}{|c|}{$\begin{array}{c}\text { (A) } \\
\text { Spraying } \\
\text { ascobin }\end{array}$}} & Without & 36.07 & 11.74 & 394.29 & 4.74 & 4.40 & 4.93 & 1.89 \\
\hline & & with & 36.55 & 11.76 & 393.26 & 4.76 & 4.42 & 4.94 & 1.90 \\
\hline & & $F$ & NS & NS & NS & NS & NS & NS & NS \\
\hline & & $\mathrm{LSD}_{05}$ & & & & & & & \\
\hline \multirow{5}{*}{\multicolumn{2}{|c|}{$\begin{array}{l}\stackrel{(B)}{\text { Irrigation }} \\
\text { intervals }\end{array}$}} & 1 week & 41.06 & 13.54 & 462.52 & 5.60 & 5.54 & 5.41 & 2.12 \\
\hline & & 2 weeks & 35.99 & 11.74 & 393.69 & 4.90 & 4.40 & 4.98 & 1.91 \\
\hline & & 3 weeks & 31.88 & 9.98 & 325.12 & 3.75 & 3.29 & 4.40 & 1.65 \\
\hline & & $\mathrm{F}$ & $2513.73^{*}$ & $2512.22^{*}$ & $2517.82^{*}$ & 2091.26* & $2452.71^{*}$ & $2234.26^{\star}$ & $2438.35^{\star}$ \\
\hline & & $\mathrm{LSD}_{05}$ & 0.30 & 0.12 & 4.46 & 0.07 & 0.07 & 0.04 & 0.02 \\
\hline \multirow{6}{*}{\multicolumn{2}{|c|}{$\begin{array}{c}\text { (C) } \\
\text { Supper } \\
\text { Phosphate }\end{array}$}} & 0 & 35.60 & 11.46 & 382.36 & 4.52 & 4.21 & 4.83 & 1.84 \\
\hline & & 50 & 36.01 & 11.65 & 390.03 & 4.70 & 4.34 & 4.88 & 1.87 \\
\hline & & 75 & 36.50 & 11.85 & 397.20 & 4.80 & 4.48 & 4.96 & 1.91 \\
\hline & & 100 & 37.13 & 12.06 & 405.51 & 4.97 & 4.61 & 5.06 & 1.95 \\
\hline & & $\mathrm{F}$ & $19.00^{*}$ & $27.67^{\star}$ & $36.12^{*}$ & $89.03^{*}$ & $88.79^{*}$ & $23.16^{\star}$ & $41.06^{\star}$ \\
\hline & & $\mathrm{LSD}_{05}$ & 0.43 & 0.14 & 4.73 & 0.06 & 0.05 & 0.06 & 0.02 \\
\hline
\end{tabular}

Regarding the irrigation intervals, the results in Tables (6 and 7) reveal a significantly decreases in soil available $\mathrm{N}, \mathrm{P}$ and $\mathrm{K}$ with increasing irrigation intervals from one to three weeks in the first season and from three to five weeks in the second one led to the decrease were $31.88,9.98$ and 325.12 
El-Maddah, E. I. et al.

ppm in the first season and $31.03,10.12$ and $304.26 \mathrm{ppm}$ in the second one for $\mathrm{N}, \mathrm{P}$ and $\mathrm{K}$, respectively.

Table (7):Effect of different treatments on soil macro and micronutrients in the second season

\begin{tabular}{|c|c|c|c|c|c|c|c|c|c|}
\hline \multirow{2}{*}{ 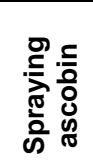 } & \multirow{2}{*}{ 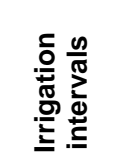 } & \multirow{2}{*}{ 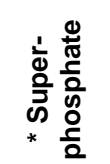 } & \multicolumn{3}{|c|}{$\begin{array}{c}\text { Available macronutrients } \\
(\mathrm{ppm})\end{array}$} & \multicolumn{4}{|c|}{$\begin{array}{l}\text { DTPA- extractable micronutrients } \\
(\text { (ppm) }\end{array}$} \\
\hline & & & $\mathbf{N}$ & $\mathbf{P}$ & K & $\mathrm{Fe}$ & $M n$ & $\mathrm{Zn}$ & $\mathrm{Cu}$ \\
\hline \multirow{12}{*}{ without } & \multirow{4}{*}{3 week } & 0 & 39.09 & 13.71 & 438.09 & 5.51 & 5.11 & 5.17 & 1.88 \\
\hline & & 50 & 39.54 & 13.93 & 445.31 & 5.63 & 5.19 & 5.22 & 1.91 \\
\hline & & 75 & 40.11 & 14.14 & 452.55 & 5.79 & 5.26 & 5.26 & 1.95 \\
\hline & & 100 & 40.67 & 14.36 & 460.16 & 5.94 & 5.40 & 5.34 & 1.99 \\
\hline & \multirow{4}{*}{4 weeks } & 0 & 34.30 & 11.74 & 364.58 & 4.39 & 3.50 & 4.38 & 1.58 \\
\hline & & 50 & 34.76 & 11.96 & 372.61 & 4.48 & 3.65 & 4.47 & 1.63 \\
\hline & & 75 & 35.10 & 12.15 & 381.85 & 4.76 & 4.17 & 4.66 & 1.68 \\
\hline & & 100 & 35.78 & 12.38 & 391.49 & 4.86 & 4.26 & 4.74 & 1.71 \\
\hline & \multirow{4}{*}{5 weeks } & 0 & 30.21 & 9.76 & 291.18 & 3.27 & 2.56 & 3.85 & 1.25 \\
\hline & & 50 & 30.47 & 9.98 & 299.53 & 3.58 & 2.62 & 3.93 & 1.30 \\
\hline & & 75 & 30.81 & 10.23 & 309.59 & 3.69 & 2.71 & 4.00 & 1.33 \\
\hline & & 100 & 31.27 & 10.45 & 317.28 & 3.87 & 2.82 & 4.06 & 1.35 \\
\hline \multirow{12}{*}{ with } & \multirow{4}{*}{3 week } & 0 & 39.20 & 13.71 & 438.66 & 5.58 & 5.15 & 5.16 & 1.92 \\
\hline & & 50 & 39.65 & 13.95 & 446.50 & 5.73 & 5.19 & 5.23 & 1.96 \\
\hline & & 75 & 40.77 & 14.18 & 453.33 & 5.78 & 5.27 & 5.28 & 1.98 \\
\hline & & 100 & 41.57 & 14.37 & 462.15 & 5.95 & 5.43 & 5.38 & 2.01 \\
\hline & \multirow{4}{*}{4 weeks } & 0 & 34.32 & 11.73 & 366.62 & 4.40 & 3.58 & 4.51 & 1.60 \\
\hline & & 50 & 34.99 & 11.93 & 374.65 & 4.55 & 3.77 & 4.57 & 1.64 \\
\hline & & 75 & 35.68 & 12.15 & 383.08 & 4.70 & 4.15 & 4.70 & 1.70 \\
\hline & & 100 & 36.02 & 12.46 & 389.95 & 5.00 & 4.36 & 4.83 & 1.72 \\
\hline & \multirow{4}{*}{5 weeks } & 0 & 30.88 & 9.83 & 292.61 & 3.41 & 2.57 & 3.86 & 1.26 \\
\hline & & 50 & 31.22 & 10.02 & 300.75 & 3.49 & 2.62 & 3.91 & 1.32 \\
\hline & & 75 & 31.45 & 10.21 & 307.98 & 3.55 & 2.72 & 3.99 & 1.34 \\
\hline & & 100 & 31.91 & 10.45 & 315.20 & 3.68 & 2.83 & 4.03 & 1.36 \\
\hline \multicolumn{3}{|c|}{ Control } & 34.30 & 11.74 & 364.58 & 4.39 & 3.50 & 4.38 & 1.58 \\
\hline \multirow{4}{*}{\multicolumn{2}{|c|}{$\begin{array}{c}\text { (A) } \\
\text { Spraying } \\
\text { ascobin }\end{array}$}} & Without & 35.17 & 12.07 & 377.02 & 4.65 & 3.94 & 4.59 & 1.63 \\
\hline & & with & 35.64 & 12.08 & 377.62 & 4.65 & 3.97 & 4.62 & 1.65 \\
\hline & & $\mathrm{F}$ & NS & NS & NS & NS & NS & NS & NS \\
\hline & & $\mathrm{LSD}_{05}$ & & & & & & & \\
\hline \multirow{5}{*}{\multicolumn{2}{|c|}{$\begin{array}{l}\quad(B) \\
\text { Irrigation } \\
\text { intervals }\end{array}$}} & 3 weeks & 40.07 & 14.04 & 449.59 & 5.74 & 5.25 & 5.26 & 1.95 \\
\hline & & 4 weeks & 35.12 & 12.06 & 378.10 & 4.64 & 3.93 & 4.61 & 1.66 \\
\hline & & 5 weeks & 31.03 & 10.12 & 304.26 & 3.57 & 2.68 & 3.95 & 1.31 \\
\hline & & $\mathrm{F}$ & $\begin{array}{c}2518.97 \\
*\end{array}$ & $2542.76^{\star}$ & $\underset{*}{2538.98}$ & $2636.81^{*}$ & $2506.95^{\star}$ & $2568.11^{\star}$ & 2967.34* \\
\hline & & $\mathrm{LSD}_{05}$ & 0.29 & 0.13 & 4.70 & 0.07 & 0.08 & 0.04 & 0.02 \\
\hline \multirow{6}{*}{\multicolumn{2}{|c|}{$\begin{array}{c}(\mathrm{C}) \\
\text { Supper } \\
\text { Phosphate }\end{array}$}} & 0 & 34.66 & 11.75 & 365.29 & 4.43 & 3.74 & 4.49 & 1.58 \\
\hline & & 50 & 35.10 & 11.96 & 373.23 & 4.58 & 3.84 & 4.55 & 1.63 \\
\hline & & 75 & 35.65 & 12.18 & 381.40 & 4.71 & 4.05 & 4.65 & 1.66 \\
\hline & & 100 & 36.20 & 12.41 & 389.37 & 4.88 & 4.18 & 4.73 & 1.69 \\
\hline & & $\mathrm{F}$ & $20.48^{*}$ & $31.84^{*}$ & $43.52^{*}$ & $103.76^{*}$ & $141.71^{*}$ & $30.34^{*}$ & $46.57^{*}$ \\
\hline & & $\mathrm{LSD}_{05}$ & 0.42 & 0.15 & 4.52 & 0.05 & 0.05 & 0.06 & 0.02 \\
\hline
\end{tabular}


Regarding superphosphate addition, the results show that increasing phosphorus levels from zero to $100 \%$ of the recommended dose caused an increases in available N, P and K of the soil, the increases were 37.13, 12.06 and $405.51 \mathrm{ppm}$ in the first season, and $36.20,12.41$ and $389.37 \mathrm{ppm}$ in the second one, respectively.

Concerning spraying ascobin, data reveal that there is no wide variation between different treatments on available $\mathrm{N}, \mathrm{P}$ and $\mathrm{K}$ of the soil.

\section{Soil micronutrients.}

Data in Tables (6 and 7) show that all different treatments led to change in the soil micronutrients concentration ( $\mathrm{Fe}, \mathrm{Mn}, \mathrm{Zn}$ and $\mathrm{Cu}$ ) at the end of the two seasons compared with the control. The maximum values of $\mathrm{Fe}, \mathrm{Mn}, \mathrm{Zn}$ and $\mathrm{Cu}$ concentrations were recorded by irrigation intervals every one week in the first season and three weeks in the second one with $100 \%$ of recommended dose of phosphorus levels addition and spraying ascobin, where they increased by $24.95,37.80,16.05$ and $24.04 \%$ in the first season and $35.54,55.14,22.83$ and $27.22 \%$ in the second one, respectively. While, the minimum values of the concentration of soil micronutrients were obtained by irrigation intervals every three weeks in the first season and five weeks in the second one without phosphorus addition and spraying ascobin.

On the other hand, increasing irrigation intervals from one to three weeks in the first season and from three to five weeks in the second one led to significantly decreases in the concentration of $\mathrm{Fe}, \mathrm{Mn}, \mathrm{Zn}$ and $\mathrm{Cu}$ of the soil, the values were decreased from 5.60, 5.54, 5.41 and $212 \mathrm{ppm}$ in the first season and $5.74,5.25,5.26$ and $1.95 \mathrm{ppm}$ in the second one, respectively, to be $3.75,3.29,4.40$ and $1.65 \mathrm{ppm}$ and $3.57,2.68,3.95$ and $1.31 \mathrm{ppm}$ in the first and second seasons, respectively. Also, increasing superphosphate addition from zero to $100 \%$ of the recommended dose caused significantly increase in the concentrations of $\mathrm{Fe}, \mathrm{Mn}, \mathrm{Zn}$ and $\mathrm{Cu}$ of the soil. The increases were ranged from 4.52 to $4.97,4.21$ to $4.61,4.83$ to 5.06 and 1.84 to $1.95 \mathrm{ppm}$ in the first season and from 4.43 to $4.88,3.74$ to $4.18,4.49$ to 4.73 and 1.58 to $1.69 \mathrm{ppm}$ in the second one, respectively. Similar results were obtained by Fouda et al., (2005), who reported that the concentration of heavy metals in the soil increased with application of phosphatic fertilizers. Non significant variation were detected with ascobin foliar application in the first and second seasons on soil micronutrients.

\section{Effect of different treatments on chemical composition of plants.}

\section{Macronutrients concentrations and its uptake.}

The results in Tables ( 8 and 9$)$ indicate that all different treatments caused changes in the concentrations and uptake of macronutrients $(N, P$ and $\mathrm{K}$ ) in maize and wheat grains in the first and second seasons. The highest values of $\mathrm{N}, \mathrm{P}$ and $\mathrm{K}$ concentrations and uptake were obtained by irrigation intervals every two or four weeks in the first and second seasons with $100 \%$ of recommended dose of phosphorus addition and spraying ascobin, where the values increased by $5.38,11.76,9.71 \%$ and 16.35 , $23.70,21.13 \%$ of maize grains in the first season and $7.52,14.00,11.92 \%$ and $21.04,26.23,24.06 \%$ of wheat grains in the second one for the concentrations and uptake of $\mathrm{N}, \mathrm{P}$ and $\mathrm{K}$, respectively as compared with control. While, the lowest values were resulted by irrigation intervals every 
three or five weeks in the first and second seasons with the same addition of phosphorus and ascobin.

Regarding to irrigation intervals, results reveal that the concentrations and uptake of $\mathrm{N}, \mathrm{P}$ and $\mathrm{K}$ by maize and wheat grains were significantly decreased by increasing irrigation intervals to three or five weeks in the first and second seasons. The maximum values of $\mathrm{N}, \mathrm{P}$ and $\mathrm{K}$ concentrations and uptake by maize and wheat plants were recorded by irrigation intervals every two or four weeks, the increases were $1.737,0.522,0.550 \%$ and 50.52 , $15.43,16.36 \mathrm{Kg} \mathrm{fed}^{-1}$ for maize grains in the first season and $1.622,0.474$, $0.524 \%$ and $39.05,12.38,13.68 \mathrm{Kg}^{-1} \mathrm{fed}^{-1}$ for wheat grains in the second one, respectively. The minimum values of $\mathrm{N}, \mathrm{P}$ and $\mathrm{K}$ concentrations and uptake were obtained by irrigation intervals every three or five weeks, which were $1.533,0.406,0.446 \%$ and $41.25,10.55,11.48 \mathrm{Kg}^{-1} \mathrm{~d}^{-1}$ for maize grains and $1.440,0.352,0.403 \%$ and $30.52,8.30,9.35 \mathrm{Kg} \mathrm{fed}^{-1}$ for wheat grains. These results reveal that irrigation intervals every two or four weeks were more effective upon increase the concentrations and uptake of $\mathrm{N}, \mathrm{P}$ and $\mathrm{K}$, which take the following order : 2 weeks $>1$ week $>3$ weeks in the first season and 4 weeks $>3$ weeks $>5$ weeks in the second one. These results agree with Khamis (1987), who reported that increasing soil moisture content caused a highly significant increase in concentrations and uptake of $\mathrm{N}, \mathrm{P}$ and $\mathrm{K}$ by broad bean seeds and shoots.

Regarding to superphosphate addition, the results declear that the concentrations and uptake of $\mathrm{N}, \mathrm{P}$ and $\mathrm{K}$ by maize and wheat grains were increased by increasing phosphorus levels from zero to $100 \%$ of recommended dose, where the highest values increased to $1.652,0.472$, $0.506 \%$ and $47.02,13.46,14.39 \mathrm{Kg} \mathrm{fed}^{-1}$ and $1.546,0.422,0.472 \%$ and $35.96,10.47,11.66 \mathrm{Kg} \mathrm{fed}^{-1}$ for maize and wheat grains, respectively. Similar conclusions were obtained by Hanna et al., (1996) and Barsoom (1998), who found that NPK concentration and uptake in broad bean seeds and straw were increased due to phosphorus application to soil.

Concerning ascobin foliar application, the results in Tables (8 and 9) show that the concentrations and uptake of $\mathrm{N}, \mathrm{P}$ and $\mathrm{K}$ of maize and wheat grains in the first and second seasons were significantly affected by spraying ascobin, where spraying ascobin increased the concentrations and uptake of $\mathrm{N}, \mathrm{P}$ and $\mathrm{K}$, which reached to $1.656,0.477,0.509 \%$ and $47.57,13.68,14.60$ $\mathrm{Kg} \mathrm{fed}^{-1}$ of maize grains and reached to $1.551,0.425,0.475 \%$ and 36.31 , $10.62,11.80 \mathrm{Kg} \mathrm{fed}^{-1}$ of wheat grains as compared with the treatments without spraying ascobin (untreated ones). These results may be due to ascobin foliar enhancing the accumulation of nontoxic metabolites (sugars, amino acids, proline and protein) and improving levels of $\mathrm{N}, \mathrm{P}$ and $\mathrm{K}$ (Sheteawi, 2007). Similar results were obtained by Abd El-Aziz et al., (2006), who reported that the percentage and uptake of $\mathrm{N}, \mathrm{P}$ and $\mathrm{K}$ tended to increase by increasing the concentration of ascorbic acid up to $400 \mathrm{ppm}$ as compared to the untreated ones. 
Table (8): Effect of different treatments on macronutrients concentration (\%) and uptake (Kg fed-1) of maize grains in the first season.

\begin{tabular}{|c|c|c|c|c|c|c|c|c|}
\hline \multirow{2}{*}{$\begin{array}{l}\text { Spraying } \\
\text { ascobin }\end{array}$} & \multirow{2}{*}{$\begin{array}{l}\text { Irrigation } \\
\text { intervals }\end{array}$} & \multirow{2}{*}{$\begin{array}{c}\text { * Super- } \\
\text { phosphate }\end{array}$} & \multicolumn{3}{|c|}{ Concentration, \% } & \multicolumn{3}{|c|}{ Uptake, Kg fed-1 } \\
\hline & & & $\mathbf{N}$ & $\mathbf{P}$ & $\mathrm{K}$ & $\mathbf{N}$ & $\mathbf{P}$ & $\mathrm{K}$ \\
\hline \multirow{12}{*}{ without } & \multirow{4}{*}{1 week } & 0 & 1.608 & 0.446 & 0.479 & 42.17 & 11.69 & 12.55 \\
\hline & & 50 & 1.618 & 0.453 & 0.486 & 43.84 & 12.22 & 13.11 \\
\hline & & 75 & 1.633 & 0.461 & 0.493 & 44.65 & 12.59 & 13.47 \\
\hline & & 100 & 1.638 & 0.463 & 0.498 & 45.41 & 12.95 & 13.91 \\
\hline & \multirow{4}{*}{2 weeks } & 0 & 1.693 & 0.493 & 0.525 & 46.86 & 13.84 & 14.81 \\
\hline & & 50 & 1.709 & 0.502 & 0.533 & 48.03 & 14.31 & 15.24 \\
\hline & & 75 & 1.724 & 0.510 & 0.539 & 49.40 & 14.85 & 15.78 \\
\hline & & 100 & 1.727 & 0.517 & 0.545 & 49.54 & 15.07 & 15.96 \\
\hline & \multirow{4}{*}{3 weeks } & 0 & 1.501 & 0.382 & 0.428 & 38.27 & 9.41 & 10.40 \\
\hline & & 50 & 1.506 & 0.387 & 0.433 & 38.64 & 9.58 & 10.58 \\
\hline & & 75 & 1.518 & 0.396 & 0.439 & 39.28 & 9.88 & 10.82 \\
\hline & & 100 & 1.523 & 0.397 & 0.440 & 40.07 & 10.14 & 11.11 \\
\hline \multirow{12}{*}{ with } & \multirow{4}{*}{1 week } & 0 & 1.644 & 0.467 & 0.500 & 45.82 & 13.10 & 14.04 \\
\hline & & 50 & 1.645 & 0.468 & 0.500 & 46.13 & 13.12 & 14.06 \\
\hline & & 75 & 1.654 & 0.473 & 0.506 & 47.27 & 13.52 & 14.45 \\
\hline & & 100 & 1.660 & 0.474 & 0.510 & 47.54 & 13.65 & 14.69 \\
\hline & \multirow{4}{*}{2 weeks } & 0 & 1.739 & 0.527 & 0.553 & 50.83 & 15.63 & 16.46 \\
\hline & & 50 & 1.757 & 0.536 & 0.560 & 51.94 & 16.08 & 17.27 \\
\hline & & 75 & 1.767 & 0.543 & 0.569 & 53.04 & 16.56 & 17.39 \\
\hline & & 100 & 1.784 & 0.551 & 0.576 & 54.52 & 17.12 & 17.94 \\
\hline & \multirow{4}{*}{3 weeks } & 0 & 1.532 & 0.411 & 0.449 & 41.70 & 10.76 & 11.67 \\
\hline & & 50 & 1.544 & 0.419 & 0.456 & 42.62 & 11.13 & 12.02 \\
\hline & & 75 & 1.560 & 0.424 & 0.461 & 44.35 & 11.61 & 12.52 \\
\hline & & 100 & 1.581 & 0.431 & 0.466 & 45.05 & 11.84 & 12.72 \\
\hline \multicolumn{3}{|c|}{ Control } & 1.693 & 0.493 & 0.525 & 46.86 & 13.84 & 14.81 \\
\hline \multirow{4}{*}{\multicolumn{2}{|c|}{$\begin{array}{l}\text { (A) } \\
\text { Spraying } \\
\text { ascobin }\end{array}$}} & Without & 1.616 & 0.451 & 0.486 & 43.85 & 12.21 & 13.14 \\
\hline & & with & 1.656 & 0.477 & 0.509 & 47.57 & 13.68 & 14.60 \\
\hline & & $\mathrm{F}$ & $580.22^{*}$ & $574.73^{*}$ & $585.68^{*}$ & $581.66^{*}$ & $602.15^{*}$ & $551.10^{*}$ \\
\hline & & $\mathrm{LSD}_{05}$ & 0.007 & 0.005 & 0.004 & 0.66 & 0.26 & 0.27 \\
\hline \multirow{5}{*}{\multicolumn{2}{|c|}{$\begin{array}{l}\qquad \mathrm{B}) \\
\text { Irrigation } \\
\text { intervals }\end{array}$}} & 1 week & 1.638 & 0.463 & 0.496 & 45.35 & 12.85 & 13.78 \\
\hline & & 2 weeks & 1.737 & 0.522 & 0.550 & 50.52 & 15.43 & 16.36 \\
\hline & & 3 weeks & 1.533 & 0.406 & 0.446 & 41.25 & 10.55 & 11.48 \\
\hline & & $\mathrm{F}$ & $1176.34^{*}$ & 1157.89* & 1153.98* & 1163.49* & $1156.87^{*}$ & $1173.25^{*}$ \\
\hline & & $\mathrm{LSD}_{05}$ & 0.010 & 0.006 & 0.005 & 0.44 & 0.23 & 0.23 \\
\hline \multirow{6}{*}{\multicolumn{2}{|c|}{$\begin{array}{c}\text { (C) } \\
\text { Supper } \\
\text { Phosphate }\end{array}$}} & 0 & 1.620 & 0.454 & 0.489 & 44.27 & 12.40 & 13.32 \\
\hline & & 50 & 1.630 & 0.461 & 0.495 & 45.20 & 12.74 & 13.71 \\
\hline & & 75 & 1.643 & 0.468 & 0.501 & 46.33 & 13.17 & 14.07 \\
\hline & & 100 & 1.652 & 0.472 & 0.506 & 47.02 & 13.46 & 14.39 \\
\hline & & $\mathrm{F}$ & $9.87^{*}$ & $39.05^{*}$ & $28.46^{\star}$ & $97.80^{*}$ & $177.39^{*}$ & $150.45^{\star}$ \\
\hline & & $\mathrm{LSD}_{05}$ & 0.013 & 0.004 & 0.004 & 0.35 & 0.10 & 0.11 \\
\hline
\end{tabular}


El-Maddah, E. l. et al.

Table (9): Effect of different treatments on macronutrients concentration (\%) and uptake ( $\mathrm{Kg} \mathrm{fed-1)}$ of wheat grains in the second season.

\begin{tabular}{|c|c|c|c|c|c|c|c|c|}
\hline \multirow[b]{2}{*}{$\begin{array}{l}\text { Spraying } \\
\text { ascobin }\end{array}$} & \multirow[b]{2}{*}{$\begin{array}{l}\text { Irrigation } \\
\text { intervals }\end{array}$} & \multirow{2}{*}{$\begin{array}{l}\text { * Super- } \\
\text { phosphate }\end{array}$} & \multicolumn{3}{|c|}{ Concentration, \% } & \multicolumn{3}{|c|}{ Uptake, Kg fed-1 } \\
\hline & & & $\mathbf{N}$ & $\mathbf{P}$ & K & $\mathbf{N}$ & $\mathbf{P}$ & K \\
\hline \multirow{12}{*}{ without } & \multirow{4}{*}{3 week } & 0 & 1.496 & 0.391 & 0.441 & 33.07 & 8.69 & 9.79 \\
\hline & & 50 & 1.505 & 0.398 & 0.448 & 33.49 & 9.05 & 9.97 \\
\hline & & 75 & 1.517 & 0.407 & 0.456 & 34.04 & 9.12 & 10.23 \\
\hline & & 100 & 1.528 & 0.412 & 0.463 & 34.91 & 9.46 & 10.58 \\
\hline & \multirow{4}{*}{4 weeks } & 0 & 1.569 & 0.443 & 0.495 & 35.51 & 10.98 & 12.26 \\
\hline & & 50 & 1.581 & 0.452 & 0.503 & 36.46 & 11.38 & 12.66 \\
\hline & & 75 & 1.592 & 0.461 & 0.511 & 37.27 & 11.75 & 13.04 \\
\hline & & 100 & 1.608 & 0.468 & 0.518 & 38.44 & 12.15 & 13.41 \\
\hline & \multirow{4}{*}{5 weeks } & 0 & 1.410 & 0.328 & 0.381 & 28.51 & 7.48 & 8.52 \\
\hline & & 50 & 1.417 & 0.335 & 0.388 & 29.03 & 7.72 & 8.75 \\
\hline & & 75 & 1.427 & 0.342 & 0.394 & 29.62 & 7.94 & 8.97 \\
\hline & & 100 & 1.430 & 0.344 & 0.396 & 29.90 & 8.04 & 9.08 \\
\hline \multirow{12}{*}{ with } & \multirow{4}{*}{3 week } & 0 & 1.531 & 0.415 & 0.465 & 35.63 & 9.69 & 10.86 \\
\hline & & 50 & 1.534 & 0.415 & 0.465 & 35.67 & 9.75 & 10.89 \\
\hline & & 75 & 1.539 & 0.421 & 0.470 & 35.89 & 9.82 & 10.97 \\
\hline & & 100 & 1.550 & 0.427 & 0.477 & 36.73 & 10.14 & 11.36 \\
\hline & \multirow{4}{*}{4 weeks } & 0 & 1.623 & 0.478 & 0.528 & 39.39 & 12.57 & 13.89 \\
\hline & & 50 & 1.645 & 0.488 & 0.536 & 40.67 & 13.04 & 14.33 \\
\hline & & 75 & 1.671 & 0.495 & 0.545 & 41.68 & 13.34 & 14.68 \\
\hline & & 100 & 1.687 & 0.505 & 0.554 & 42.98 & 13.86 & 15.21 \\
\hline & \multirow{4}{*}{5 weeks } & 0 & 1.443 & 0.355 & 0.406 & 30.81 & 8.42 & 9.46 \\
\hline & & 50 & 1.454 & 0.362 & 0.412 & 31.44 & 8.67 & 9.71 \\
\hline & & 75 & 1.464 & 0.370 & 0.420 & 32.04 & 8.92 & 9.98 \\
\hline & & 100 & 1.474 & 0.376 & 0.427 & 32.79 & 9.19 & 10.29 \\
\hline \multicolumn{3}{|c|}{ Control } & 1.569 & 0.443 & 0.495 & 35.51 & 10.98 & 12.26 \\
\hline \multirow{4}{*}{\multicolumn{2}{|c|}{$\begin{array}{c}\text { (A) } \\
\text { Spraying } \\
\text { ascobin }\end{array}$}} & Without & 1.507 & 0.398 & 0.449 & 33.36 & 9.48 & 10.61 \\
\hline & & with & 1.551 & 0.425 & 0.475 & 36.31 & 10.62 & 11.80 \\
\hline & & $\mathrm{F}$ & $558.76^{*}$ & $496.01^{*}$ & $545.80^{*}$ & \begin{tabular}{|l|}
$587.20^{*}$ \\
\end{tabular} & $600.20^{*}$ & $576.84^{*}$ \\
\hline & & $\mathrm{LSD}_{05}$ & 0.008 & 0.005 & 0.005 & 0.52 & 0.20 & 0.21 \\
\hline \multirow{5}{*}{\multicolumn{2}{|c|}{$\begin{array}{l}\text { (B) } \\
\text { Irrigation } \\
\text { intervals }\end{array}$}} & 3 weeks & 1.525 & 0.411 & 0.461 & 34.93 & 9.47 & 10.58 \\
\hline & & 4 weeks & 1.622 & 0.474 & 0.524 & 39.05 & 12.38 & 13.68 \\
\hline & & 5 weeks & 1.440 & 0.352 & 0.403 & 30.52 & 8.30 & 9.35 \\
\hline & & $\mathrm{F}$ & $1146.79^{\star}$ & $1137.60^{*}$ & $1138.13^{*}$ & 1157.19* & $1159.28^{*}$ & $1152.09^{*}$ \\
\hline & & $\mathrm{LSD}_{05}$ & 0.009 & 0.006 & 0.006 & 0.41 & 0.20 & 0.21 \\
\hline \multirow{6}{*}{\multicolumn{2}{|c|}{$\begin{array}{c}\text { (C) } \\
\text { Supper } \\
\text { Phosphate }\end{array}$}} & 0 & 1.512 & 0.402 & 0.453 & 33.82 & 9.64 & 10.80 \\
\hline & & 50 & 1.523 & 0.409 & 0.459 & 34.46 & 9.94 & 11.05 \\
\hline & & 75 & 1.535 & 0.416 & 0.466 & 35.09 & 10.15 & 11.31 \\
\hline & & 100 & 1.546 & 0.422 & 0.472 & 35.96 & 10.47 & 11.66 \\
\hline & & $\mathrm{F}$ & $12.14^{*}$ & $58.56^{*}$ & $47.81^{*}$ & $93.77^{*}$ & $167.11^{*}$ & $146.17^{\star}$ \\
\hline & & $\mathrm{LSD}_{05}$ & 0.012 & 0.003 & 0.003 & 0.27 & 0.08 & 0.09 \\
\hline
\end{tabular}

\section{Micronutrient concentrations and its uptake.}

Results in Tables (10 and 11) indicate that all different treatments led to changes in the concentrations and uptake of micronutrients (Fe, Mn, $\mathrm{Zn}$ and $\mathrm{Cu}$ ) of maize and wheat grains. The highest values of $\mathrm{Fe}, \mathrm{Mn}, \mathrm{Zn}$ and $\mathrm{Cu}$ concentration and uptake were recorded by irrigation intervals every two or four weeks in the first and second seasons with spraying ascobin and without 
phosphorus addition, the values were increased by $6.53,5.75,3.90,4.25 \mathrm{mg}$ $\mathrm{Kg}^{-1}$ and $12.45,11.70,9.71,11.54 \mathrm{~g} \mathrm{fed}^{-1}$ for maize grains compared with control. The concentration and uptake of wheat grains increased by 6.04 , $5.28,5.19,3.77 \mathrm{mg} \mathrm{Kg}^{-1}$ and $14.16,13.38,13.27,11.85 \mathrm{~g} \mathrm{fed}^{-1}$, respectively compared with control.

Regarding the irrigation intervals, the results reveal that the concentration and uptake of micronutrients $(\mathrm{Fe}, \mathrm{Mn}, \mathrm{Zn}$ and $\mathrm{Cu}$ ) were significantly decreased with increasing irrigation intervals, where the maximum values were recorded by irrigation intervals every two and four weeks in the first and second seasons, where the values were increased to 127.17, 49.99, 76.22, $11.63 \mathrm{mg} \mathrm{Kg}^{-1}$ and $40.01,15.73,23.97,5.04 \mathrm{~g} \mathrm{fed}^{-1}$ for maize grains and $152.74,37.36,71.70,10.68 \mathrm{mg} \mathrm{Kg}^{-1}$ and $39.58,9.68$, $18.58,2.77 \mathrm{~g} \mathrm{fed}^{-1}$ for wheat grains. The minimum values were recorded every three and five weeks in the $1^{\text {st }}$ and $2^{\text {nd }}$ season. These results means that the irrigation intervals every two weeks in the first season and four weeks in the second one were more effective than one or three weeks in the first season and three or five weeks in the second one upon increasing the concentration and uptake of micronutrients ( $\mathrm{Fe}, \mathrm{Mn}, \mathrm{Zn}$ and $\mathrm{Cu}$ ), which take the order: 2 weeks $>1$ week $>3$ weeks in the first season and 4 weeks $>3$ weeks $>5$ weeks in the second one. Similar conclusion was obtained by ElNaggar et al., (1991), who found that the concentration and uptake of micro elements in grain and straw of wheat increased as soil moisture stress decreased.

Concerning superphosphate addition, the results show that the values of $\mathrm{Fe}, \mathrm{Mn}, \mathrm{Zn}$ and $\mathrm{Cu}$ concentrations and uptake by maize and wheat plants were significantly decreased by increasing phosphorus levels from zero to $100 \%$ of the recommended dose. The highest values are 116.28, 46.28, $72.28,11.05 \mathrm{mg} \mathrm{Kg}^{-1}$ and $32.55,12.93,20.12,4.12 \mathrm{~g}^{-1}$ fed maize grains and $139.65,34.85,66.76,10.14 \mathrm{mg} \mathrm{Kg}^{-1}$ and $33.70,8.14,15.60,2.36 \mathrm{~g} \mathrm{fed}^{-1}$ for wheat grains, which obtained without superphosphate addition. The lowest values are $112.67,45.08,70.94,10.79 \mathrm{mg} \mathrm{Kg}^{-1}$ and $30.20,12.05$, $18.89,3.80 \mathrm{~g} \mathrm{fed}^{-1}$ for maize grains and 135.14, 34.02, 65.13, $9.96 \mathrm{mg} \mathrm{Kg}^{-1}$ and $31.69,7.70,14.75,2.25 \mathrm{~g} \mathrm{fed}^{-1}$ for wheat grains, which obtained by added $100 \%$ of phosphorus levels in the first and second seasons. These results agree with Barsoom (1998) and Fouda et al., (2005) which detected a significant reduction decrease of $\mathrm{Cu}, \mathrm{Zn}$ and $\mathrm{Mn}$ uptake by increasing phosphorus fertilizers. 
El-Maddah, E. l. et al.

Table (10): Effect of different treatments on DTPA- extractable metals ( $\mathrm{mg} \mathrm{Kg}-1$ ) and uptake ( $\mathrm{g}$ fed-1) of maize grains in the first season.

\begin{tabular}{|c|c|c|c|c|c|c|c|c|c|c|}
\hline \multirow{2}{*}{ 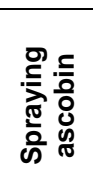 } & \multirow{2}{*}{ 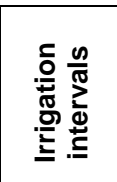 } & \multirow{2}{*}{ 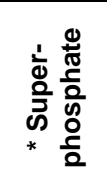 } & \multicolumn{4}{|c|}{$\begin{array}{c}\text { DTPA- extractable } \\
\text { micronutrients (mg Kg-1) }\end{array}$} & \multicolumn{4}{|c|}{ Uptake micronutrients, $g$ fed-1 } \\
\hline & & & $\mathrm{Fe}$ & Mn & $\mathrm{Zn}$ & $\mathrm{Cu}$ & $\mathrm{Fe}$ & $\mathbf{M n}$ & $\mathrm{Zn}$ & $\mathrm{Cu}$ \\
\hline \multirow{12}{*}{ without } & \multirow{4}{*}{1 week } & 0 & 113.42 & 45.23 & 71.23 & 10.87 & 30.59 & 12.20 & 19.21 & 3.89 \\
\hline & & 50 & 112.16 & 44.71 & 70.70 & 10.78 & 29.41 & 11.72 & 18.54 & 3.77 \\
\hline & & 75 & 111.19 & 44.60 & 70.43 & \begin{tabular}{|l|}
10.71 \\
\end{tabular} & 29.13 & 11.66 & 18.35 & 3.79 \\
\hline & & 100 & \begin{tabular}{|l|}
110.64 \\
\end{tabular} & 44.27 & 70.09 & \begin{tabular}{|l|}
10.65 \\
\end{tabular} & 27.99 & 11.23 & 17.76 & 3.54 \\
\hline & \multirow{4}{*}{2 weeks } & 0 & 125.39 & 49.41 & 75.66 & 11.54 & 39.27 & \begin{tabular}{|l|}
15.47 \\
\end{tabular} & 23.69 & 4.94 \\
\hline & & 50 & 123.68 & 48.86 & 75.07 & 11.41 & 37.97 & 15.00 & 3.05 & 4.83 \\
\hline & & 75 & 122.32 & 48.27 & 74.45 & 11.32 & 37.07 & 14.63 & 22.56 & 4.76 \\
\hline & & 100 & 121.07 & 47.74 & 73.89 & 11.25 & 35.88 & 14.15 & 90 & 4.46 \\
\hline & \multirow{4}{*}{3 weeks } & 0 & 100.72 & 41.11 & 66.73 & 10.24 & 22.04 & 9.00 & 14.60 & 2.87 \\
\hline & & 50 & 99.25 & 40.73 & \begin{tabular}{|l|}
66.18 \\
\end{tabular} & 9.83 & 21.54 & 8.84 & 14.36 & 2.85 \\
\hline & & 75 & 97.56 & 40.24 & 65.56 & 9.78 & 21.01 & 8.66 & 14.12 & 2.82 \\
\hline & & 100 & 96.64 & 39.98 & 65.31 & 9.74 & 20.59 & 8.52 & 13.92 & 2.69 \\
\hline \multirow{12}{*}{ with } & \multirow{4}{*}{1 week } & 0 & 118.11 & 46.74 & \begin{tabular}{|l|}
72.82 \\
\end{tabular} & \begin{tabular}{|l|}
11.09 \\
\end{tabular} & 33.75 & 13.36 & 0.81 & 4.26 \\
\hline & & 50 & 116.70 & 46.36 & 72.37 & 11.03 & 5 & 0 & 20.28 & 4.18 \\
\hline & & 75 & 116.63 & 46.33 & 72.33 & 11.03 & 32.64 & \begin{tabular}{|l|}
12.96 \\
\end{tabular} & 20.15 & 4.21 \\
\hline & & 100 & 116.44 & 46.24 & 72.25 & 11.00 & 32.50 & \begin{tabular}{|l|}
12.88 \\
\end{tabular} & 20.13 & 4.06 \\
\hline & \multirow{4}{*}{2 weeks } & 0 & 133.58 & 52.25 & 78.61 & $\mid 12.03$ & 44.16 & \begin{tabular}{|l|}
17.28 \\
\end{tabular} & 25.99 & 5.51 \\
\hline & & 50 & 132.01 & 51.69 & 77.85 & 11.93 & 42.94 & \begin{tabular}{|l|}
16.81 \\
\end{tabular} & 25.32 & 5.41 \\
\hline & & 75 & 130.45 & 51.12 & 77.43 & 11.81 & 41.85 & 16.40 & 24.84 & 5.33 \\
\hline & & 100 & 128.87 & 50.56 & 76.84 & \begin{tabular}{|l|}
11.73 \\
\end{tabular} & 40.95 & \begin{tabular}{|l|}
16.07 \\
\end{tabular} & 24.42 & 5.07 \\
\hline & \multirow{4}{*}{3 weeks } & 0 & 106.43 & 42.90 & 68.63 & 10.53 & 25.46 & 10.26 & \begin{tabular}{|l|}
16.42 \\
\end{tabular} & 3.27 \\
\hline & & 50 & 105.03 & 42.46 & 68.16 & 10.48 & 24.69 & 9.98 & 16.02 & 3.21 \\
\hline & & 75 & 103.42 & 42.06 & \begin{tabular}{|l|}
67.69 \\
\end{tabular} & \begin{tabular}{|l|}
10.41 \\
\end{tabular} & 23.29 & 9.48 & 15.29 & 3.08 \\
\hline & & 100 & 102.35 & 41.69 & 67.29 & \begin{tabular}{|l|}
10.37 \\
\end{tabular} & 23.28 & 9.47 & \begin{tabular}{|l|}
15.25 \\
\end{tabular} & 2.99 \\
\hline \multicolumn{3}{|c|}{ Control } & 125.39 & 49.41 & 75.66 & 11.54 & 39.27 & \begin{tabular}{|l|}
15.47 \\
\end{tabular} & 23.69 & 4.94 \\
\hline \multirow{4}{*}{\multicolumn{2}{|c|}{$\begin{array}{c}\text { (A) } \\
\text { Spraying } \\
\text { ascobin }\end{array}$}} & Without & 111.17 & 44.60 & 70.44 & 10.68 & 29.37 & 11.76 & 18.50 & 3.77 \\
\hline & & with & 117.50 & 46.70 & 72.69 & 11.12 & 33.19 & 13.16 & 20.41 & 4.22 \\
\hline & & $\mathrm{F}$ & $584.37^{*}$ & $582.05^{\star}$ & $576.40^{*}$ & $590.15^{\star}$ & $581.14^{*}$ & 567.73* & $578.06^{*}$ & $600.98^{*}$ \\
\hline & & $\mathrm{LSD}_{05}$ & 1.13 & 0.38 & 0.40 & 0.08 & 0.68 & 0.25 & 0.34 & 0.08 \\
\hline \multirow{5}{*}{\multicolumn{2}{|c|}{$\begin{array}{l}\text { (B) } \\
\text { Irrigation } \\
\text { intervals }\end{array}$}} & 1 week & 114.41 & 45.56 & 71.53 & 10.90 & 31.09 & \begin{tabular}{|l|}
12.38 \\
\end{tabular} & \begin{tabular}{|l|}
19.40 \\
\end{tabular} & 3.96 \\
\hline & & 2 weeks & $\mid 127.17$ & 49.99 & 76.22 & 11.63 & 40.01 & \begin{tabular}{|l|}
15.73 \\
\end{tabular} & 23.97 & 5.04 \\
\hline & & 3 weeks & 101.43 & 41.40 & 66.94 & \begin{tabular}{|l|}
10.17 \\
\end{tabular} & 22.74 & 9.28 & 15.00 & 2.97 \\
\hline & & $F$ & $1160.42^{*}$ & $160.49^{*}$ & 159.83* & 143.37 & 1159.88 & $1173.62^{*}$ & $1165.60^{*}$ & $1130.12^{*}$ \\
\hline & & $\mathrm{LSD}_{05}$ & 1.23 & 0.41 & 0.44 & \begin{tabular}{|l|}
0.07 \\
\end{tabular} & 0.83 & 0.31 & 0.43 & 0.10 \\
\hline \multirow{6}{*}{\multicolumn{2}{|c|}{$\begin{array}{l}\text { (C) } \\
\text { Supper } \\
\text { Phosphate }\end{array}$}} & 0 & 116.28 & 46.28 & \begin{tabular}{|l|}
72.28 \\
\end{tabular} & 11.05 & 32.55 & 12.93 & 20.12 & 4.12 \\
\hline & & 50 & 114.81 & 45.80 & 71.72 & 10.91 & 31.55 & 12.56 & 19.60 & 4.04 \\
\hline & & 75 & 113.59 & 45.44 & 71.32 & 10.84 & 30.83 & 12.30 & 19.22 & 4.00 \\
\hline & & 100 & 112.67 & 45.08 & 70.94 & \begin{tabular}{|l|}
10.79 \\
\end{tabular} & 30.20 & \begin{tabular}{|l|}
12.05 \\
\end{tabular} & \begin{tabular}{|l|}
18.89 \\
\end{tabular} & 3.80 \\
\hline & & $\mathrm{F}$ & $24.67^{*}$ & $16.52^{*}$ & $8.38^{*}$ & $14.03^{*}$ & $137.29^{*}$ & $120.02^{*}$ & $97.06^{*}$ & $154.99^{*}$ \\
\hline & & $\mathrm{LSD}_{05}$ & 0.90 & 0.36 & 0.57 & 0.09 & 0.25 & 0.10 & 0.15 & 0.03 \\
\hline
\end{tabular}


Table (11): Effect of different treatments on DTPA- extractable metals (mg Kg-1) and uptake ( $\mathrm{g}$ fed-1) of wheat grains in the second season.

\begin{tabular}{|c|c|c|c|c|c|c|c|c|c|c|}
\hline \multirow{2}{*}{ 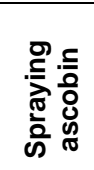 } & \multirow{2}{*}{ 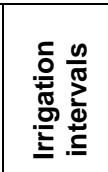 } & \multirow{2}{*}{ 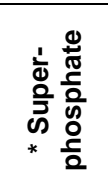 } & \multicolumn{4}{|c|}{$\begin{array}{c}\text { DTPA- extractable } \\
\text { micronutrients (mg Kg-1) }\end{array}$} & \multicolumn{4}{|c|}{ Uptake micronutrients, g fed- 1} \\
\hline & & & $\mathrm{Fe}$ & Mn & $\mathrm{Zn}$ & $\mathrm{Cu}$ & $\mathrm{Fe}$ & Mn & $\mathrm{Zn}$ & $\mathrm{Cu}$ \\
\hline \multirow{12}{*}{ without } & \multirow{4}{*}{3 week } & 0 & 136.64 & 34.16 & 65.53 & 10.01 & 30.40 & 7.60 & 14.58 & 2.23 \\
\hline & & 50 & 134.48 & 33.82 & 64.87 & 9.94 & 29.72 & 7.48 & 14.32 & 2.20 \\
\hline & & 75 & 133.44 & 33.69 & 64.47 & 9.89 & 29.64 & 7.45 & 14.30 & 2.19 \\
\hline & & 100 & 132.90 & 33.47 & 64.12 & 9.87 & 28.88 & 7.27 & 13.94 & 2.14 \\
\hline & \multirow{4}{*}{4 weeks } & 0 & 150.90 & 36.96 & 70.92 & 10.60 & 38.48 & 9.42 & 18.08 & 2.70 \\
\hline & & 50 & 149.07 & 36.59 & 70.25 & 10.53 & 37.51 & 9.21 & 17.68 & 2.65 \\
\hline & & 75 & 147.37 & 36.20 & 69.54 & 10.43 & 36.48 & 8.96 & 17.21 & 2.58 \\
\hline & & 100 & 145.55 & 35.84 & 68.85 & 10.37 & 35.16 & 8.69 & 16.67 & 2.51 \\
\hline & \multirow{4}{*}{5 weeks } & 0 & 120.63 & 31.38 & 59.85 & 9.37 & 26.81 & 6.18 & 11.80 & 1.85 \\
\hline & & 50 & 118.81 & 31.09 & 59.10 & 9.30 & 26.13 & 6.04 & 11.49 & 1.81 \\
\hline & & 75 & 117.08 & 30.77 & 58.59 & 9.24 & 25.63 & 5.94 & 11.30 & 1.78 \\
\hline & & 100 & 115.43 & 30.52 & 58.04 & 9.19 & 25.13 & 5.84 & 11.11 & 1.76 \\
\hline \multirow{12}{*}{ with } & \multirow{4}{*}{3 week } & 0 & 141.99 & 35.16 & 67.37 & 10.23 & 32.88 & 8.18 & 15.68 & 2.37 \\
\hline & & 50 & 140.35 & 34.89 & 66.95 & 10.16 & 32.88 & 8.14 & 15.60 & 2.37 \\
\hline & & 75 & 140.20 & 34.88 & 66.86 & 10.15 & 32.58 & 8.11 & 15.55 & 2.36 \\
\hline & & 100 & 139.83 & 34.83 & 66.83 & 10.15 & 32.55 & 8.08 & 15.52 & 2.36 \\
\hline & \multirow{4}{*}{4 weeks } & 0 & 160.02 & 38.91 & 74.60 & 11.00 & 43.93 & 10.68 & 20.48 & 3.02 \\
\hline & & 50 & 158.21 & 38.53 & 73.88 & 10.92 & 42.62 & 10.38 & 19.90 & 2.94 \\
\hline & & 75 & 156.40 & 38.13 & 73.15 & 10.84 & 41.82 & 10.20 & 19.56 & 2.90 \\
\hline & & 100 & 154.37 & 37.73 & 72.36 & 10.76 & 40.63 & 9.93 & 19.04 & 2.83 \\
\hline & \multirow{4}{*}{5 weeks } & 0 & 127.74 & 32.53 & \begin{tabular}{|l|}
62.28 \\
\end{tabular} & 9.65 & 29.69 & 6.79 & 12.99 & 2.01 \\
\hline & & 50 & 125.98 & 32.23 & 61.67 & 9.56 & 28.96 & 6.63 & 12.69 & 1.97 \\
\hline & & 75 & 123.93 & 31.92 & 61.06 & 9.50 & 28.23 & 6.49 & 12.41 & 1.93 \\
\hline & & 100 & 122.74 & 31.72 & 60.57 & 9.45 & 27.78 & 6.39 & 12.20 & 1.90 \\
\hline \multicolumn{3}{|c|}{ Control } & 150.90 & 36.96 & 70.92 & 10.60 & 38.48 & 9.42 & 18.08 & 2.70 \\
\hline \multirow{4}{*}{\multicolumn{2}{|c|}{$\begin{array}{c}\text { (A ) } \\
\text { Spraying } \\
\text { ascobin }\end{array}$}} & Without & 133.53 & 33.71 & 64.51 & 9.90 & 30.83 & 7.51 & 14.37 & 2.20 \\
\hline & & with & 140.98 & 35.12 & 67.30 & 10.20 & 34.55 & 8.33 & 15.97 & 2.41 \\
\hline & & $\mathrm{F}$ & $584.11^{*}$ & $562.04^{*}$ & $580.82^{*}$ & $545.26^{\star}$ & $584.79^{\star}$ & $563.30^{*}$ & $579.36^{*}$ & $575.81^{*}$ \\
\hline & & $\mathrm{LSD}_{05}$ & 1.33 & 0.26 & 0.50 & 0.06 & 0.66 & 0.15 & 0.29 & 0.04 \\
\hline \multirow{5}{*}{\multicolumn{2}{|c|}{$\begin{array}{l}\quad(\mathrm{B}) \\
\text { Irrigation } \\
\text { intervals }\end{array}$}} & 3 weeks & 137.48 & 34.36 & 65.88 & 10.05 & 31.19 & 7.79 & 14.94 & 2.28 \\
\hline & & 4 weeks & 152.74 & 37.36 & 71.70 & 10.68 & 39.58 & 9.68 & 18.58 & 2.77 \\
\hline & & 5 weeks & 121.54 & 31.52 & 60.15 & 9.41 & 27.30 & 6.29 & 12.00 & 1.88 \\
\hline & & $\mathrm{F}$ & $1164.83^{*}$ & 163.70 & 1165.73 & 139.14 & 158.93 & 161.13 & 1156.01 & $1259.14^{*}$ \\
\hline & & $\mathrm{LSD}_{05}$ & 1.49 & 0.28 & 0.55 & 0.06 & 0.60 & 0.16 & 0.32 & 0.04 \\
\hline \multirow{6}{*}{\multicolumn{2}{|c|}{$\begin{array}{c}\text { (C) } \\
\text { Supper } \\
\text { Phosphate }\end{array}$}} & 0 & 139.65 & 34.85 & 66.76 & 10.14 & 33.70 & 8.14 & 15.60 & 2.36 \\
\hline & & 50 & 137.82 & 34.52 & 66.12 & 10.07 & 32.97 & 7.98 & 15.28 & 2.32 \\
\hline & & 75 & 136.40 & 34.27 & 65.61 & 10.01 & 32.40 & 7.86 & 15.06 & 2.29 \\
\hline & & 100 & 135.14 & 34.02 & 65.13 & 9.96 & 31.69 & 7.70 & 14.75 & 2.25 \\
\hline & & $\mathrm{F}$ & $26.43^{\star}$ & $14.10^{*}$ & $14.83^{*}$ & $7.60^{*}$ & $91.70^{*}$ & $73.62^{*}$ & $75.97^{*}$ & $56.92^{*}$ \\
\hline & & $\mathrm{LSD}_{05}$ & 1.08 & 0.27 & 0.52 & 0.08 & 0.26 & 0.06 & 0.12 & 0.02 \\
\hline
\end{tabular}

Concerning ascobin foliar of maize and wheat plants, the results indicate that the concentration and uptake by maize and wheat grains of $\mathrm{Fe}$, $\mathrm{Mn}, \mathrm{Zn}$ and $\mathrm{Cu}$ were significantly increased with twice spraying ascobin by 
the rate of $2 \mathrm{~g} / 1.5 \mathrm{~L}$. water for maize and wheat plants as compared with the treatments without spraying ascobin (untreated plants). The values of $\mathrm{Fe}, \mathrm{Mn}$, $\mathrm{Zn}$ and $\mathrm{Cu}$ concentration and uptake increased to $117.50,46.70,72.69$, $11.12 \mathrm{mg} \mathrm{Kg}^{-1}$ and $33.19,13.16,20.41,4.22 \mathrm{~g} \mathrm{fed}^{-1}$ for maize grains and 140.98, 35.12, 67.30, $10.20 \mathrm{mg} \mathrm{Kg}^{-1}$ and 34.55, 8.33, 15.97, $2.41 \mathrm{~g} \mathrm{fed}^{-1}$ for wheat grains, respectively, for the above mentioned micronutrients.

Effect of different treatments on growth characters, yield and yield components.

Most of the recorded growth characters of maize and wheat plants were significantly affected by irrigation intervals, phosphorus and ascobin foliar application. Results in Tables (12 and 13) show that the increase in maize grains yield reached to $40.61 \%$, while the increases in wheat grains and straw yield reached to 40.51 and $20.84 \%$ compared with control.

Results of Tables (12 and 13) revealed that irrigation every two weeks with $100 \%$ addition of the recommended dose of phosphorus and foliar ascobin application gave the highest values of maize grain yield which reached to 3.2077 ton/fed. in the first season. While, wheat grain and straw yield were 3.4307 and 4.4535 ton/fed. in the second season, which obtained by the same treatment except the irrigation intervals was every four weeks. However, the same treatments gave the highest values in plant height, ear length, ear diameter, number of rows per ear, number of kernels per row, 100 seed weight and dry matter of maize in the first season and in plant height, spike length, 1000 seed weight, dry matter and harvest index of wheat in the second season.

Results show that all growth characters, yield and yield components were significantly decreased by increasing irrigation intervals. The highest value of relative increasing grain yield of maize or grain and straw yield of wheat were recorded by irrigation intervals every two and four weeks, which were $20.77 \%$ for maize grains, 20.13 and $10.64 \%$ for wheat grains and straw, respectively. The lowest values of relative increasing grain yield of maize or grain and straw yield of wheat were recorded by irrigation intervals every three or five weeks in the first and second seasons, which were $4.90 \%$ for maize grains, 7.66 and $4.48 \%$ for wheat grains and straw, respectively. The other growth characters, yield and yield components take the same trend, where irrigation intervals every two weeks for maize or four weeks for wheat were more effective than the other irrigation intervals, which take the order: 2 weeks $>1$ week $>3$ weeks in the first season and 4 weeks $>3$ weeks $>5$ weeks in the second one. Similar results were obtained by Refaat and Saleh (1997) on sweet basil plant and Kandeel (2001) on Rosmarinus officinalis $L$., they reported that the plant growth was reduced by increasing irrigation intervals. 
J. Soil Sci. and Agric. Eng., Mansoura Univ., Vol. 3 (1), January, 2012 12 
El-Maddah, E. I. et al.

Table (13): Effect of different treatments on wheat yield and its components in the second season.

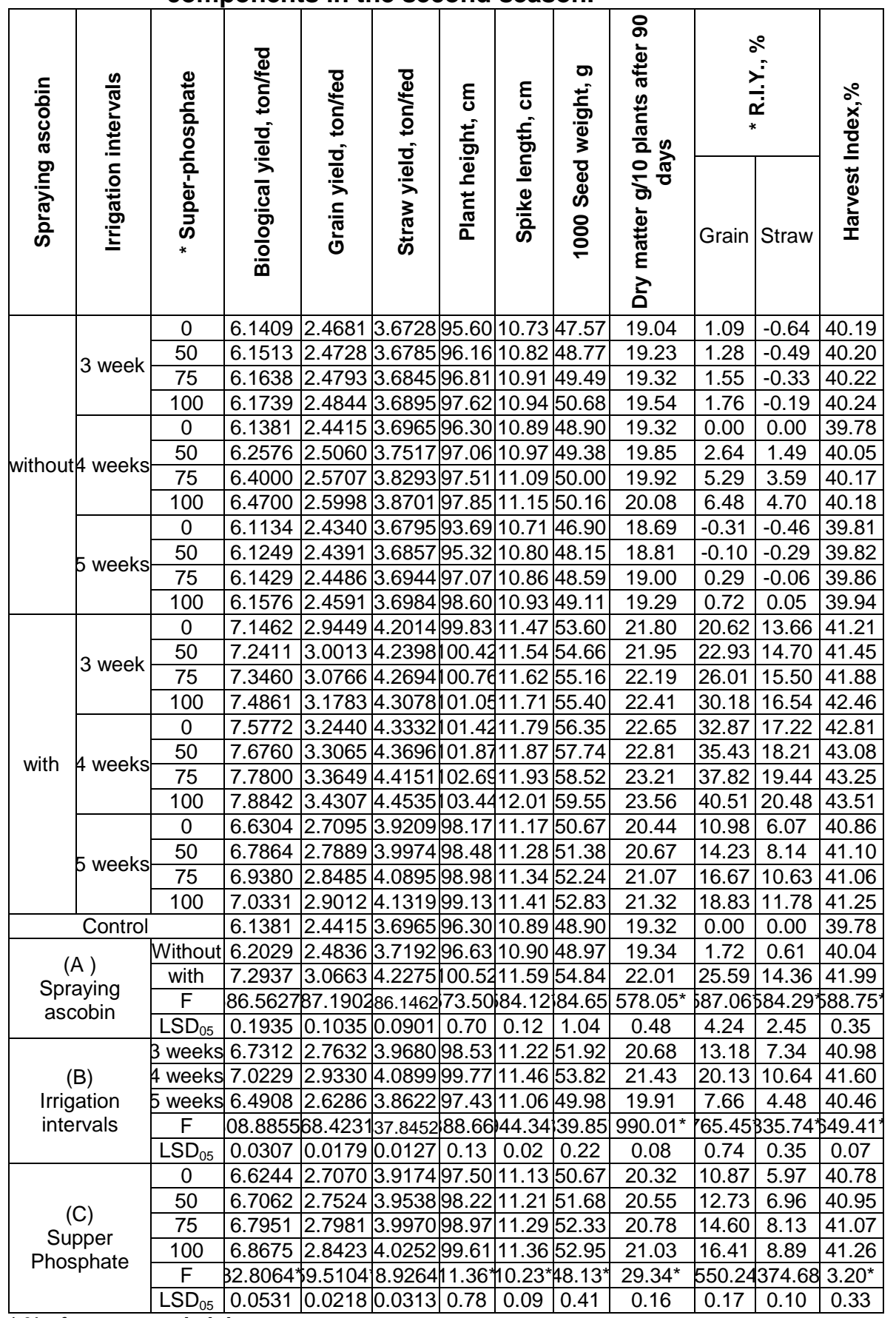


With respect to superphosphate addition, the results show that all growth characters, yield and yield components were significantly increased by increasing phosphorus levels from zero to $100 \%$ of recommended dose. The mean values of relative increasing grain yield of maize and grain and straw yield of wheat were differ between 8.66 and 14.68, 10.87 and 16.41, 5.97 and $8.89 \%$, respectively. The other growth characters, yield and yield components take the same trend. Similar results were obtained by Hussain et al., (2008) and Alias et al., (2003).

With respect to foliar ascobin application, data reveal that all growth characters, yield and yield components were significantly affected by spraying ascobin by two equal doses $(2 \mathrm{~g} / 1.5 \mathrm{~L}$ water). The mean values of relative increasing grain yield of maize were increased from 0.83 to $22.43 \%$ by spraying ascobin in the first season, while in the second season, the mean values were increased from 1.72 to $25.59 \%$ of wheat grains and from 0.61 to $14.36 \%$ of wheat straw by spraying ascobin. The same trend was found with other characters under study for maize and wheat plants. Similar results were obtained by Abd El-Aziz et al., (2006) and El-Bassiouny et al., (2005), they reported that all growth parameters tended to increase as a result of foliar spray with ascorbic acid.

Estimation of the net treatment costs.

The obtained results in Table (14) indicate that the highest net revenue value (4455.64 LE/fed.) was incorporated with the combination consists of irrigation intervals every two weeks in the first season and every four weeks in the second one at $100 \%$ of the recommended dose of phosphorus in both seasons with foliar application by ascobin, which was the best treatment and should be recommended to obtain high net revenue comparing to the other treatments.

However, it can be noticed from Table (14) that reducing or increasing irrigation intervals than the recommended period led to decreasing the yield of maize and wheat in the first and second seasons, consequently, decreasing the net revenue values. Moreover, the net revenue values were increased by increasing the addition rate of phosphorus fertilizer and by using ascobin as foliar application. 
El-Maddah, E. I. et al.

Table (14): The net revenue * (LE/fed.) due to different treatments through the two growing seasons under study.

\begin{tabular}{|c|c|c|c|c|c|c|c|c|c|}
\hline \multirow{2}{*}{ 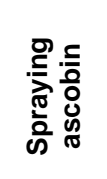 } & \multirow{2}{*}{ 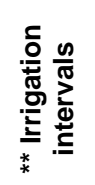 } & \multirow{2}{*}{ 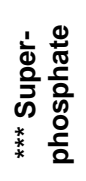 } & \multicolumn{3}{|c|}{ Increasing yield Ton/fed. } & \multicolumn{3}{|c|}{ Total yield price, LE/fed. } & \multirow{2}{*}{$\begin{array}{c}\text { Net } \\
\text { revenue } \\
\text { LE/fed. }\end{array}$} \\
\hline & & & $\begin{array}{l}\text { Maize } \\
\text { grain }\end{array}$ & $\begin{array}{l}\text { Wheat } \\
\text { grain }\end{array}$ & $\begin{array}{l}\text { Wheat } \\
\text { straw }\end{array}$ & $\begin{array}{l}\text { Maize } \\
\text { grain }\end{array}$ & $\begin{array}{l}\text { Wheat } \\
\text { grain }\end{array}$ & $\begin{array}{l}\text { Wheat } \\
\text { straw }\end{array}$ & \\
\hline \multirow{12}{*}{ without } & \multirow{4}{*}{1 or 3} & 0 & -0.0291 & 0.0266 & \begin{tabular}{|l|}
-0.0237 \\
\end{tabular} & -49.47 & 61.18 & -18.96 & -7.25 \\
\hline & & 50 & -0.0124 & 0.0313 & \begin{tabular}{|l|}
-0.0180 \\
\end{tabular} & -21.08 & 71.99 & -14.40 & 36.51 \\
\hline & & 75 & $\mid-0.0038$ & \begin{tabular}{|l|}
0.0378 \\
\end{tabular} & \begin{tabular}{|l|}
-0.0120 \\
\end{tabular} & -6.46 & 86.94 & -9.60 & 70.88 \\
\hline & & 100 & 0.0033 & 0.0429 & -0.0070 & 5.61 & 98.67 & -5.60 & 98.68 \\
\hline & \multirow{4}{*}{2 or 4} & 0 & 0.0000 & 0.0000 & \begin{tabular}{|l|}
0.0000 \\
\end{tabular} & 0.00 & 0.00 & 0.00 & 0.00 \\
\hline & & 50 & 0.0698 & 0.0645 & 0.0552 & 118.66 & \begin{tabular}{|l|}
148.35 \\
\end{tabular} & 44.16 & 311.17 \\
\hline & & 75 & 0.1498 & 0.1292 & \begin{tabular}{|l|}
0.1328 \\
\end{tabular} & 254.66 & 297.16 & 106.24 & 658.06 \\
\hline & & 100 & 0.2263 & 0.1583 & \begin{tabular}{|l|}
0.1736 \\
\end{tabular} & 384.71 & 364.09 & 138.88 & 887.68 \\
\hline & \multirow{4}{*}{3 or 5} & 0 & -0.0613 & -0.0075 & -0.0170 & -104.21 & \begin{tabular}{|l|}
-17.25 \\
\end{tabular} & -13.60 & -135.06 \\
\hline & & 50 & -0.0497 & -0.0024 & \begin{tabular}{|l|}
-0.0108 \\
\end{tabular} & -84.49 & -5.52 & -8.64 & -98.65 \\
\hline & & 75 & -0.0385 & 0.0071 & \begin{tabular}{|l|}
-0.0021 \\
\end{tabular} & -65.45 & 16.33 & -1.68 & -50.80 \\
\hline & & 100 & -0.0259 & 0.0176 & \begin{tabular}{|l|}
0.0019 \\
\end{tabular} & -44.03 & 40.48 & 1.52 & -2.03 \\
\hline \multirow{12}{*}{ with } & \multirow{4}{*}{1 or 3} & 0 & 0.3329 & 0.5034 & 0.5049 & 565.93 & 1157.82 & 403.92 & \begin{tabular}{|l|}
2127.67 \\
\end{tabular} \\
\hline & & 50 & 0.3814 & 0.5598 & \begin{tabular}{|l|}
0.5433 \\
\end{tabular} & 648.38 & 1287.54 & 434.64 & \begin{tabular}{|l|}
2370.56 \\
\end{tabular} \\
\hline & & 75 & 0.4435 & 0.6351 & \begin{tabular}{|l|}
0.5729 \\
\end{tabular} & 753.95 & 1460.73 & 458.32 & 2673.00 \\
\hline & & 100 & 0.5671 & \begin{tabular}{|l|}
0.7368 \\
\end{tabular} & \begin{tabular}{|l|}
0.6113 \\
\end{tabular} & 964.07 & \begin{tabular}{|l|}
1694.64 \\
\end{tabular} & 489.04 & \begin{tabular}{|l|}
3147.75 \\
\end{tabular} \\
\hline & \multirow{4}{*}{2 or 4} & 0 & 0.7041 & 0.8025 & \begin{tabular}{|l|}
0.6367 \\
\end{tabular} & 1196.97 & 1845.75 & 509.36 & 3552.08 \\
\hline & & 50 & 0.8271 & 0.8650 & \begin{tabular}{|l|}
0.6731 \\
\end{tabular} & 1406.07 & 1989.50 & 538.48 & 3934.05 \\
\hline & & 75 & 0.8865 & 0.9234 & 0.7186 & 1507.05 & 2123.82 & 574.88 & 4205.75 \\
\hline & & 100 & 0.9264 & 0.9892 & 0.7570 & 1574.88 & 2275.16 & 605.60 & \begin{tabular}{|l|l|}
4455.64 \\
\end{tabular} \\
\hline & \multirow{4}{*}{3 or 5} & 0 & 0.2384 & 0.2680 & \begin{tabular}{|l|}
0.2244 \\
\end{tabular} & 405.28 & 616.40 & 179.52 & 1201.20 \\
\hline & & 50 & 0.2422 & 0.3474 & 0.3009 & 411.74 & 799.02 & 240.72 & 1451.48 \\
\hline & & 75 & 0.2773 & 0.4070 & 0.3930 & 471.41 & \begin{tabular}{|l|}
936.10 \\
\end{tabular} & 314.40 & 1721.91 \\
\hline & & 100 & 0.3126 & 0.4597 & \begin{tabular}{|l|}
0.4354 \\
\end{tabular} & 531.42 & \begin{tabular}{|l|}
1057.31 \\
\end{tabular} & 348.32 & \begin{tabular}{|l|}
1937.05 \\
\end{tabular} \\
\hline \multicolumn{10}{|c|}{$=($ Yield of treatment - control $)-$ the cost of the treatment } \\
\hline \multicolumn{10}{|c|}{$\begin{array}{l}\text { The price of yield and the costs of different treatments were calculated as subsidized } \\
\text { price of } 2008 \text { and } 2009 \text {. }\end{array}$} \\
\hline \multicolumn{10}{|c|}{$\begin{array}{l}\star * \\
\text { second one }\end{array}$} \\
\hline
\end{tabular}

\section{REFERENCES}

Abd El-Aziz, N. G.; A.A.M. Mazher and E. El-Habba (2006): Effect of foliar spraying with ascorbic acid on growth and chemical constituents of Khaya senegalensis grown under salt condition. American-Eurasian J. Agric. \& Environ. Sci., 1(3):207-214

Ahmed, E.T. (1998): Influence of concentration and time spraying active yeast on growth and volatile oil content of marjoram plants. J. Agric. Sci. Mansoura Univ., 23: 5067-5081.

Alias, A.; M. Usman; E. Ullah and E. A. Warraich (2003): Effects of Different Phosphorus Levels on the Growth and Yield of Two Cultivars of Maize (Zea mays L.). Int. J. Agri. Biol., Vol. 5, No. 4: 632-634 
Barsoom, S.W. (1998): Comparative effects of inoccupation with VA mycorrhizal fungi and organic matter addition on phosphorus and micronutrients uptake by maize. Egypt. J. Soil Sci. 38, No.1-4, PP. 2133.

Cottenie, A. (1980): Soils and Plant Testing as a Basis of Fertilizer recommendation. FAO, Soil Bull., 27: 3812.

El-Bassiouny, H.M.S.; M.E. Gobarah and A.A. Ramadan (2005): Effect of Antioxidants on growth, yield and favism causative agents in seeds of Vicia faba L. plants grown under reclaimed sandy soil. J. Agron., 4(4):281-287.

El-Naggar, I.M.; T.I. El-Awag; M.H. Amer and M.M.A. El-Menoufi (1991): Response of wheat to micronutrients under different soil moisture tention. Egypt. J. Appl. Sci., 6(10):333-345.

El-Sodany, M. El-D. and E. I. El-Maddah (2009): Effect of organic matter and inorganic phosphorus application on some chemical properties and soil phosphorus fractions. J. Agric. Mansoura Univ., 34(3):2357-2380

El-Sodany, M. El-D.; E. I. El-Maddah and K.A. Khatab (2009): Effect of organic matter and inorganic phosphorus application on some physical, hydrophysical properties and soil productivity. Egypt J. of Appl. Sci., 24(7): 396-421.

El-Tawil, A.Y. (2003): Effect of irrigation intervals and some nutrients application on broad bean production, nutrients uptake and some water relations in different soils. J. Agric. Sci. Mansoura Univ., 28(4):32273245.

Ezz El-Din, A. and M.Y. Khalil (2003): Effect of foliar fertilization on growth and yield of two Plantago species cultivated in Egypt. Egypt. J. Hort., 30: 227-237.

Fouda, E.E.; N.N. youssef; E.A. Abdel-Bary and Nesreen S. Mohsen (2005): Assessment of the effectiveness of type and level of phosphatic fertilizer on heavy metal and phosphorus content of alfalfa. Zagazig J. Agric. Res., 32(2):543-562.

Ghaly, N.G. and M. El-D. El-Sodany (2009): Effect of irrigation intervals and active dry yeast foliar application on nigella sativa I. plant and some soil properties at El-Gharbia governorate. Egypt. J. of Appl. Sci., 24(5A):249-272

Hanna, A.M.; I.M. El-Naggar and T.I. El-Awag (1996): Effect of methods of phosphorus application and soil moisture levels on broad bean yield, nutrients content and some water relations. J. Agric. Sci. Mansoura Univ., 21(4):1479-1489.

Havlin, J.L; J. Beaton; S.L. Tisdale and W.L. Nelson. (1999): Soil Fertility and Fertilizers. $6^{\text {th }}$ Edition. Prentice Hall. N.J.

Hesse, P. P. (1971): A Text Book of Soil Chemical Analysis -John- Murray (pupils.), London Great Britan.

Hussain, N.; M.B. Khan and R. Ahmad (2008): Influence of phosphorus application and sowing time on performance of wheat in calcareous soils. Int. J. Agri. Biol., 10(4): 399-404

Israelsen, O. W. and V. E. Hansen (1962): "Irrigation principles and practices". $3^{\text {rd }}$ Edit. John Wiley and Sons. Inc. New York. 
Jakson, M.L. (1973): Soil Chemical Analysis. Prentice. Hall, inc. Englewood Cliffe, NewJersey.

Jensen, M. E. (1983): Design and operation of farm irrigation system. Am. Soc. Agric. Eng. Micbigan U.S.A.

Kandeel, A.M. (2001): Effect of irrigation intervals on the growth and active ingredients of Rosmarinus officinalis L. plants. Arab Univ. J. Agric. Sci., Ain Shams Univ., Cairo, 9(2): 825-838.

Khamis, M.A.M. (1987): Evaluation of some crops under different soil and water management in sandy soil. M.Sc. Thesis, Fac. of Agric., Zagazig Univ., Egypt.

Lindsay, W.L. and A. Norevell (1978): Development of DTPA test for zinc, iron, manganese and copper. SoilSci. Soc. Amer. J., 42:421-428.

Mohamed, K.A.; A.A. Rayan and H.M. Eid (1995): Response of seed cotton yield and water consumptive use to different irrigation regimes. Proc. Of the $2^{\text {nd }}$ Conf. on Far. Irrig. and Agrocli. January 2-, 1995,pp. 290299.

Mohamed, S.A. and N.Y. Naguib (2002): Influence of foliar sprays with potassin $\mathrm{P}, \mathrm{N}$, Ascobin and their combination on yield parameters and chemical constituents of seeds of fenugreek plants. Arab Univ. J. Agric., Ain Shams Univ. Cairo., 10:879-891.

Nimje P. M. and J. Seth (1986): Effect of phosphorus, farmyard manure and nitrogen on some soil properties in a soya bean-maize sequence. J. Agric. Sci., 107:555-559

Page, A.L.; R.H. Miller and D.R. Keeney (1982): Methods of Soil Analysis. Part 2. Chemical and Microbiological properties. Second Edition. Madison, Wisconsin, USA.

Refaat, A.M. and M.M. Saleh (1997): The combined effect of irrigation intervals and foliar nutrition on sweet basil plants. Bulletin Fac. Agric. Cairo Univ., 48(3):515-527.

Richards, R. L. (1954): Diagnosis and improvement of saline and alkali soils. Agriculture Handbook No. 60, US Guvt. Printing office, Washington.

Sendecor, G.W. and W.G. Cochran (1981): Statistical methods. $7^{\text {th }}$ Ed. lowa State Univ. Press, Ames. lowa, USA, pp. 305-310.

Sheteawi, S. A. (2007): Improving Growth and Yield of Salt-stressed Soybean by Exogenous Application of Jasmonic Acid and Ascobin. Int. J. Agri. Biol., Vol. 9, No. 3: 473-478

Soomro A.; M.S. Mirjat; F.C. Oad; H. Soomro; M.A. Samo and N.L. Oad (2001): Effect of irrigation intervals on soil salinity and cotton yield. Online J. of Biological Sci., 1(6): 472-474.

Stakman, W. P. (1969): Determination of soil moisture retention curves. I. Sand-box apparatus. II. Pressure membrane apparatus. ICU, Wageningen, The Netherlands.

Sultani, M. I.; M. A. Gill; M. M. Anwar and M. Athar (2007): Evaluation of soil physical properties as influenced by various green manuring legumes and phosphorus fertilization under rain fed conditions. Int. J. Environ. Sci. Tech., 4 (1): 109-118 
Talaat, N.B. (2003): Physiological studies on the effect of salinity, ascorbic acid and putrescine of sweet pepper plant. Ph.D. Thesis, Fac. Agric., Cairo Univ., Egypt.

Vomocil, J.A. (1986): Particle-Size Analysis " in : Methods of Soil Analysis " C.F. Klute, A. (Ed.) Part 1- Agron. 9, 15:299, Am. Soc. Agron. Madison, Wisconsin, U.S.A.

Ziadah, K.A.; O.A. Nofal; A.M. Hamissa and E.I. El-Maddah (2000): Effect of irrigation intervals, potassium levels and bioregulator SGA-1 application on chemical composition, productivity and water use efficiency of cotton (Giza 70 cutivar). Minufiya J. Agric. Res. Vol. 25 No. 2: 339-370.

تأثير فترات الري ومستويات من الفوسفور والرش بحمض الاسكوربيك والستريك

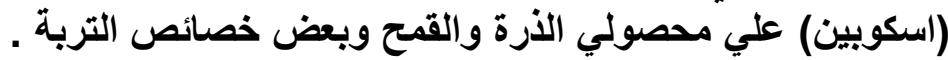

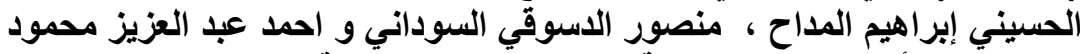

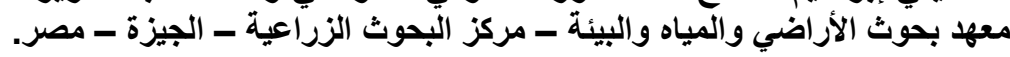

اجريت تجارب حقليه علي ارض طينيه في مزر عاده محطه البحوث الزر اعيه بالجميزه ، محافظه

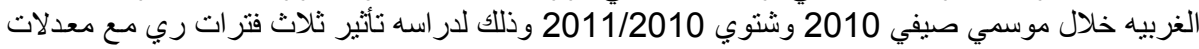

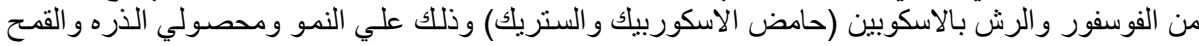

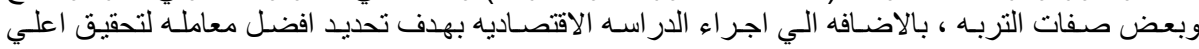
صافي دخل مزرعي. ويمكن تلخيص النتائتج المتحصل عليها كالتالي:-

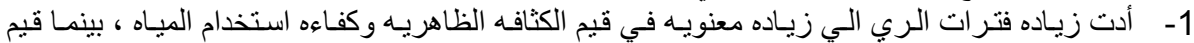

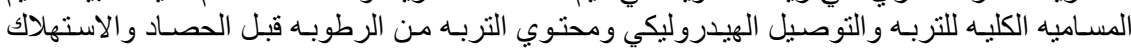

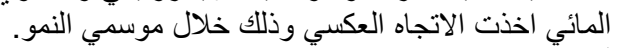

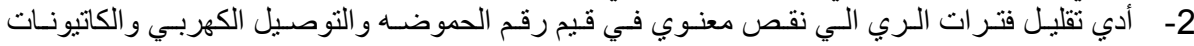

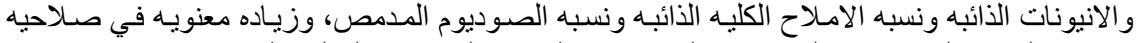

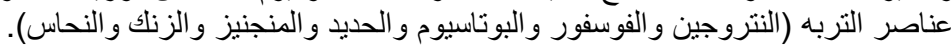

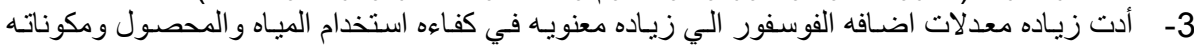

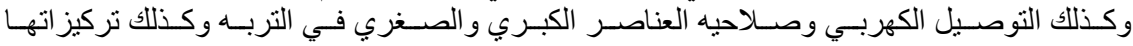
و وامتصاصها في الحبوب في كلا الكوسمين.

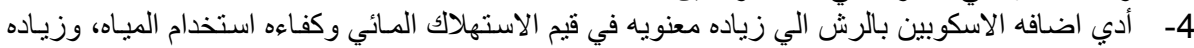

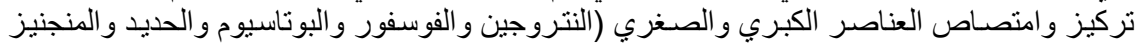

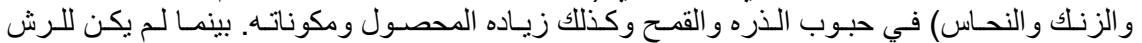

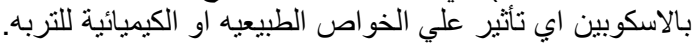

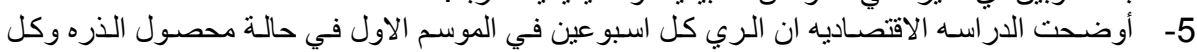

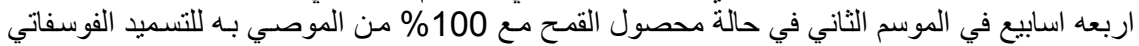

والرش بالاسكوبين في كلا الموسمين هي احسن معامله من الوجهة الاقتصادية.

كلية الزراعة - جامعة المنصورة كلية الزراعة - جامعة الزقازيق المراعة
قام بتحكيم البحث

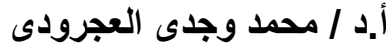

أ. أد / كرم فؤاد موسى وجى العجرو 
El-Maddah, E. I. et al. 
J. Soil Sci. and Agric. Eng., Mansoura Univ., Vol. 3 (1): 63 - 93, 2012

Table (4): Effect of different treatments on some soil chemical properties in the first season

\begin{tabular}{|c|c|c|c|c|c|c|c|c|c|c|c|c|c|c|}
\hline \multirow{2}{*}{$\begin{array}{l}\text { Spraying } \\
\text { ascobin }\end{array}$} & \multirow{2}{*}{$\begin{array}{l}\text { Irrigation } \\
\text { intervals }\end{array}$} & \multirow{2}{*}{$\begin{array}{l}{ }^{*} \text { Super- } \\
\text { phosphate }\end{array}$} & \multirow{2}{*}{$\begin{array}{l}\text { Soil pH } \\
1: 2.5 \\
\text { susp. }\end{array}$} & \multirow{2}{*}{$\begin{array}{l}\mathrm{EC} \\
\mathrm{dSm}^{-1}\end{array}$} & \multicolumn{4}{|c|}{ Soluble cations, meq/l } & \multicolumn{4}{|c|}{ Soluble anions, meq/l } & \multirow{2}{*}{ TSS,\% } & \multirow{2}{*}{ SAR } \\
\hline & & & & & $\mathrm{Ca}$ & Mg & $\mathrm{Na}$ & K & $\mathrm{CO}_{3}$ & $\mathrm{HCO}_{3}$ & $\mathrm{Cl}$ & $\mathrm{SO}_{4}$ & & \\
\hline \multirow{12}{*}{ without } & \multirow{4}{*}{1 week } & 0 & 7.65 & 2.49 & 8.70 & 6.77 & 9.02 & 0.33 & 0.00 & 5.29 & 10.63 & 8.90 & 0.09 & 3.24 \\
\hline & & 50 & 7.64 & 2.53 & 8.75 & 6.97 & 9.13 & 0.34 & 0.00 & 4.82 & 11.25 & 9.11 & 0.09 & 3.26 \\
\hline & & 75 & 7.63 & 2.56 & 8.83 & 7.04 & 9.30 & 0.35 & 0.00 & 4.47 & 11.75 & 9.30 & 0.11 & 3.30 \\
\hline & & 100 & 7.62 & 2.61 & 8.93 & 7.09 & 9.64 & 0.36 & 0.00 & 4.23 & 12.25 & 9.52 & 0.12 & 3.41 \\
\hline & \multirow{4}{*}{2 weeks } & 0 & 7.74 & 2.65 & 8.80 & 7.07 & 10.17 & 0.35 & 0.00 & 4.94 & 12.50 & 8.95 & 0.10 & 3.61 \\
\hline & & 50 & 7.73 & 2.67 & 8.90 & 7.12 & 10.32 & 0.36 & 0.00 & 4.59 & 12.88 & 9.23 & 0.11 & 3.65 \\
\hline & & 75 & 7.72 & 2.70 & 9.00 & 7.17 & 10.51 & 0.36 & 0.00 & 4.12 & 13.25 & 9.67 & 0.12 & 3.70 \\
\hline & & 100 & 7.71 & 2.73 & 9.05 & 7.27 & 10.63 & 0.37 & 0.00 & 3.65 & 13.63 & 10.04 & 0.12 & 3.72 \\
\hline & \multirow{4}{*}{3 weeks } & 0 & 7.83 & 2.79 & 8.85 & 7.17 & 11.38 & 0.37 & 0.00 & 4.47 & 13.14 & 10.16 & 0.11 & 4.02 \\
\hline & & 50 & 7.82 & 2.83 & 8.95 & 7.22 & 11.64 & 0.38 & 0.00 & 4.23 & 13.38 & 10.58 & 0.12 & 4.10 \\
\hline & & 75 & 7.81 & 2.87 & 9.00 & 7.37 & 11.81 & 0.39 & 0.00 & 4.00 & 13.88 & 10.69 & 0.13 & 4.13 \\
\hline & & 100 & 7.80 & 2.92 & 9.15 & 7.47 & 12.11 & 0.41 & 0.00 & 3.65 & 14.04 & 11.44 & 0.14 & 4.20 \\
\hline \multirow{12}{*}{ with } & \multirow{4}{*}{1 week } & 0 & 7.64 & 2.47 & 8.70 & 6.75 & 8.95 & 0.33 & 0.00 & 5.35 & 10.59 & 8.79 & 0.08 & 3.22 \\
\hline & & 50 & 7.63 & 2.51 & 8.75 & 7.00 & 9.02 & 0.35 & 0.00 & 5.15 & 11.25 & 8.71 & 0.09 & 3.21 \\
\hline & & 75 & 7.61 & 2.55 & 8.85 & 7.05 & 9.27 & 0.36 & 0.00 & 4.76 & 12.00 & 8.76 & 0.11 & 3.29 \\
\hline & & 100 & 7.60 & 2.58 & 8.95 & 7.15 & 9.42 & 0.36 & 0.00 & 4.41 & 12.50 & 8.98 & 0.12 & 3.32 \\
\hline & \multirow{4}{*}{2 weeks } & 0 & 7.73 & 2.63 & 8.80 & 7.05 & 10.21 & 0.36 & 0.00 & 4.76 & 12.50 & 9.16 & 0.09 & 3.63 \\
\hline & & 50 & 7.72 & 2.66 & 8.88 & 7.08 & 10.40 & 0.37 & 0.00 & 4.41 & 12.75 & 9.55 & 0.10 & 3.68 \\
\hline & & 75 & 7.71 & 2.69 & 8.99 & 7.12 & 10.54 & 0.38 & 0.00 & 4.17 & 13.13 & 9.72 & 0.11 & 3.71 \\
\hline & & 100 & 7.70 & 2.72 & 9.05 & 7.20 & 10.70 & 0.38 & 0.00 & 3.82 & 13.50 & 10.01 & 0.13 & 3.75 \\
\hline & \multirow{4}{*}{3 weeks } & 0 & 7.82 & 2.77 & 8.85 & 7.15 & 11.20 & 0.38 & 0.00 & 4.29 & 12.88 & 10.41 & 0.11 & 3.96 \\
\hline & & 50 & 7.81 & 2.81 & 8.93 & 7.33 & 11.37 & 0.39 & 0.00 & 4.06 & 13.25 & 10.71 & 0.12 & 3.99 \\
\hline & & 75 & 7.80 & 2.86 & 9.05 & 7.40 & 11.62 & 0.40 & 0.00 & 3.94 & 13.63 & 10.91 & 0.13 & 4.05 \\
\hline & & 100 & 7.79 & 2.91 & 9.15 & 7.45 & 11.97 & 0.41 & 0.00 & 3.70 & 13.88 & 11.40 & 0.14 & 4.16 \\
\hline \multicolumn{3}{|c|}{ Control } & 7.74 & 2.65 & 8.80 & 7.07 & 10.17 & 0.35 & 0.00 & 4.94 & 12.50 & 8.95 & 0.10 & 3.61 \\
\hline \multirow{4}{*}{\multicolumn{2}{|c|}{$\begin{array}{c}\text { (A) } \\
\text { Spraying } \\
\text { ascobin }\end{array}$}} & Without & 7.72 & 2.70 & 8.91 & 7.14 & 10.47 & 0.36 & 0.00 & 4.37 & 12.71 & 9.80 & 0.11 & 3.69 \\
\hline & & with & 7.71 & 2.68 & 8.91 & 7.14 & 10.39 & 0.37 & 0.00 & 4.40 & 12.65 & 9.76 & 0.11 & 3.66 \\
\hline & & $\mathrm{F}$ & NS & NS & & & & & & & & & NS & NS \\
\hline & & $\mathrm{LSD}_{05}$ & & & & & & & & & & & & \\
\hline \multirow{5}{*}{\multicolumn{2}{|c|}{$\begin{array}{l}\text { (B) } \\
\text { Irrigation } \\
\text { intervals }\end{array}$}} & 1 week & 7.63 & 2.54 & 8.81 & 6.98 & 9.22 & 0.35 & 0.00 & 4.81 & 11.53 & 9.01 & 0.10 & 3.28 \\
\hline & & 2 weeks & 7.72 & 2.68 & 8.93 & 7.13 & 10.43 & 0.37 & 0.00 & 4.31 & 13.02 & 9.54 & 0.11 & 3.68 \\
\hline & & 3 weeks & 7.81 & 2.85 & 8.99 & 7.32 & 11.64 & 0.39 & 0.00 & 4.04 & 13.51 & 10.79 & 0.13 & 4.08 \\
\hline & & $\mathrm{F}$ & $1843.15^{*}$ & $1840.94^{*}$ & & & & & & & & & $90.76^{*}$ & $2576.81^{\star}$ \\
\hline & & $\mathrm{LSD}_{05}$ & 0.01 & 0.01 & & & & & & & & & 0.00 & 0.03 \\
\hline \multirow{6}{*}{\multicolumn{2}{|c|}{$\begin{array}{c}\text { (C) } \\
\text { Supper } \\
\text { Phosphate }\end{array}$}} & 0 & 7.73 & 2.63 & 8.78 & 6.99 & 10.15 & 0.36 & 0.00 & 4.85 & 12.04 & 9.40 & 0.10 & 3.61 \\
\hline & & 50 & 7.72 & 2.67 & 8.86 & 7.12 & 10.31 & 0.36 & 0.00 & 4.54 & 12.46 & 9.65 & 0.11 & 3.65 \\
\hline & & 75 & 7.71 & 2.71 & 8.95 & 7.19 & 10.51 & 0.37 & 0.00 & 4.24 & 12.94 & 9.84 & 0.12 & 3.70 \\
\hline & & 100 & 7.70 & 2.75 & 9.05 & 7.27 & 10.75 & 0.38 & 0.00 & 3.91 & 13.30 & 10.23 & 0.13 & 3.76 \\
\hline & & $\mathrm{F}$ & NS & $19.01^{*}$ & & & & & & & & & $361.86^{*}$ & $17.03^{*}$ \\
\hline & & $\mathrm{LSD}_{05}$ & & 0.03 & & & & & & & & & 0.002 & 0.04 \\
\hline
\end{tabular}

* $\%$ of recommended dose 
El-Maddah, E. l. et al.

Table (5): Effect of different treatments on some soil chemical properties in the second season

\begin{tabular}{|c|c|c|c|c|c|c|c|c|c|c|c|c|c|c|}
\hline \multirow{2}{*}{$\begin{array}{l}\text { Spraying } \\
\text { ascobin }\end{array}$} & \multirow{2}{*}{$\begin{array}{l}\text { Irrigation } \\
\text { intervals }\end{array}$} & \multirow{2}{*}{$\begin{array}{l}\text { * Super- } \\
\text { phosphate }\end{array}$} & \multirow{2}{*}{$\begin{array}{l}\text { Soil pH } \\
1: 2.5 \\
\text { susp. }\end{array}$} & \multirow{2}{*}{$\mathrm{dS}^{\mathrm{E}} \mathrm{m}^{-1}$} & \multicolumn{4}{|c|}{ Soluble cations, meq/l } & \multicolumn{4}{|c|}{ Soluble anions, meq/l } & \multirow{2}{*}{ TSS, \% } & \multirow{2}{*}{ SAR } \\
\hline & & & & & $\mathrm{Ca}$ & Mg & $\mathrm{Na}$ & K & $\mathrm{CO}_{3}$ & $\mathrm{HCO}_{3}$ & $\mathrm{Cl}$ & $\mathrm{SO}_{4}$ & & \\
\hline \multirow{10}{*}{ without } & \multirow{3}{*}{3 week } & 0 & 7.59 & 2.38 & 8.14 & 7.09 & 8.40 & 0.25 & 0.00 & 5.17 & 10.78 & 7.92 & 0.08 & $\frac{3.04}{3.10}$ \\
\hline & & 50 & 7.58 & 2.41 & 8.19 & 7.14 & 8.59 & 0.26 & 0.00 & 4.94 & 11.15 & 8.09 & 0.09 & $\frac{3.10}{3.18}$ \\
\hline & & $\frac{75}{100}$ & 7.57 & $\begin{array}{l}2.45 \\
2.49\end{array}$ & $\frac{8.29}{8.44}$ & 7.19 & $\frac{8.85}{9.10}$ & $\begin{array}{l}0.27 \\
0.28\end{array}$ & $\begin{array}{l}0.00 \\
0.00\end{array}$ & 4.82 & $\begin{array}{l}11.65 \\
12.15\end{array}$ & 8.12 & $\begin{array}{l}0.10 \\
012\end{array}$ & $\frac{3.18}{3.25}$ \\
\hline & \multirow{3}{*}{4 weeks } & 0 & 7.69 & 2.53 & 8.14 & 7.24 & $\frac{9.10}{9.76}$ & 0.27 & 0.00 & $\begin{array}{l}4.59 \\
4.94\end{array}$ & $\begin{array}{l}12.15 \\
12.40\end{array}$ & $\begin{array}{l}8.26 \\
8.07\end{array}$ & $\frac{0.12}{0.09}$ & $\begin{array}{l}3.25 \\
3.52 \\
\end{array}$ \\
\hline & & 50 & 7.67 & 2.57 & 8.19 & 7.34 & 10.00 & 0.28 & 0.00 & 4.82 & 12.78 & 8.21 & 0.10 & 3.59 \\
\hline & & 75 & 7.67 & 2.61 & 8.27 & 7.41 & 10.23 & 0.29 & 0.00 & 4.59 & 13.15 & 8.45 & 0.11 & $\begin{array}{l}3.65 \\
3.72\end{array}$ \\
\hline & \multirow{4}{*}{5 weeks } & $\begin{array}{c}100 \\
0\end{array}$ & $\begin{array}{l}7.66 \\
7.80\end{array}$ & $\frac{2.65}{270}$ & $\begin{array}{l}8.37 \\
8.59\end{array}$ & 7.46 & $\begin{array}{l}10.48 \\
10.49\end{array}$ & 0.29 & 0.00 & $\begin{array}{l}4.35 \\
4.70\end{array}$ & $\begin{array}{l}13.53 \\
1304\end{array}$ & $\begin{array}{l}8.72 \\
92.25\end{array}$ & 0.12 & $\begin{array}{l}3.72 \\
3.69\end{array}$ \\
\hline & & 50 & 7.79 & 2.74 & 8.69 & 7.71 & 10.67 & 0.30 & 0.00 & 4.47 & 13.28 & 9.63 & 0.12 & $\frac{3.69}{3.73}$ \\
\hline & & 75 & 7.78 & 2.78 & 8.74 & 7.81 & 10.92 & 0.31 & 0.00 & 4.39 & 13.78 & 9.62 & 0.13 & 3.80 \\
\hline & & 100 & 7.76 & 2.84 & 8.84 & 7.91 & 11.31 & 0.33 & 0.00 & 4.08 & 14.03 & 10.28 & 0.14 & 3.91 \\
\hline \multirow{12}{*}{ with } & \multirow{4}{*}{3 week } & 0 & 7.58 & 2.37 & 8.05 & 7.03 & 8.29 & 0.25 & 0.00 & 5.17 & 10.66 & 7.78 & 0.08 & 3.02 \\
\hline & & 50 & 7.58 & 2.40 & 8.13 & 7.05 & 8.57 & 0.27 & 0.00 & 4.94 & 11.15 & 7.93 & 0.09 & 3.11 \\
\hline & & 75 & 7.56 & 2.43 & 8.25 & 7.07 & 8.74 & 0.28 & 0.00 & 4.82 & 11.90 & 7.62 & 0.10 & 3.16 \\
\hline & & 100 & 7.55 & 2.47 & 8.35 & 7.10 & 8.98 & 0.29 & 0.00 & 4.59 & 12.40 & 7.73 & 0.12 & 3.23 \\
\hline & \multirow{4}{*}{4 weeks } & 0 & 7.68 & 2.52 & 8.55 & 7.15 & 9.24 & 0.29 & 0.00 & 4.94 & 12.40 & 7.89 & 0.09 & 3.30 \\
\hline & & 50 & 7.68 & 2.55 & 8.60 & 7.20 & 9.43 & 0.29 & 0.00 & 4.70 & 12.65 & 8.17 & 0.10 & 3.36 \\
\hline & & 75 & 7.67 & 2.59 & 8.70 & 7.25 & 9.58 & 0.30 & 0.00 & 4.47 & 13.03 & 8.33 & 0.11 & 3.39 \\
\hline & & 100 & 7.65 & 2.62 & 8.80 & 7.30 & 9.74 & 0.31 & 0.00 & 4.35 & 13.40 & 8.39 & 0.12 & 3.43 \\
\hline & \multirow{4}{*}{5 weeks } & 0 & 7.79 & 2.69 & 8.45 & 7.65 & 10.54 & 0.31 & 0.00 & 4.59 & 12.78 & 9.58 & 0.11 & 3.71 \\
\hline & & 50 & 7.78 & 2.72 & 8.55 & 7.70 & 10.76 & 0.31 & 0.00 & 4.47 & 13.15 & 9.70 & 0.11 & 3.77 \\
\hline & & 75 & 7.77 & 2.76 & 8.65 & 7.75 & 11.01 & 0.32 & 0.00 & 4.35 & 13.53 & 9.85 & 0.12 & 3.84 \\
\hline & & 100 & 7.75 & 2.82 & 8.80 & 7.80 & 11.27 & 0.33 & 0.00 & 4.12 & 13.78 & 10.31 & 0.14 & 3.91 \\
\hline \multicolumn{3}{|c|}{ Control } & 7.69 & 2.53 & 8.14 & 7.24 & 9.76 & 0.27 & 0.00 & 4.94 & 12.40 & 8.07 & 0.09 & 3.52 \\
\hline \multirow{4}{*}{\multicolumn{2}{|c|}{$\begin{array}{l}\text { (A) } \\
\text { Spraying } \\
\text { ascobin }\end{array}$}} & Without & 7.68 & 2.60 & 8.41 & 7.42 & 9.90 & 0.29 & 0.00 & 4.65 & 12.64 & 8.72 & 0.11 & 3.52 \\
\hline & & with & 7.67 & 2.58 & 8.49 & 7.34 & 9.68 & 0.30 & 0.00 & 4.63 & 12.57 & 8.61 & 0.11 & 3.44 \\
\hline & & $F$ & NS & NS & & & & & & & & & NS & NS \\
\hline & & $\frac{L^{2} D_{05}}{3}$ & 757 & 242 & 823 & 710 & 869 & 027 & 000 & 488 & 1148 & 793 & 0.10 & 3.14 \\
\hline \multirow{4}{*}{\multicolumn{2}{|c|}{$\begin{array}{l}\text { (B) } \\
\text { Irrigation } \\
\text { intervals }\end{array}$}} & 4 weeks & 7.67 & 2.42 & 8.45 & $\begin{array}{l}1.10 \\
7.29\end{array}$ & 9.81 & 0.29 & 0.00 & $\begin{array}{l}4.88 \\
4.64\end{array}$ & $\begin{array}{l}11.48 \\
12.92\end{array}$ & $\begin{array}{l}7.93 \\
8.28\end{array}$ & 0.10 & $\begin{array}{l}3.14 \\
3.50\end{array}$ \\
\hline & & 5 weeks & 7.78 & 2.76 & 8.66 & 7.74 & 10.87 & 0.31 & 0.00 & 4.40 & 13.42 & 9.78 & 0.12 & 3.80 \\
\hline & & $\mathrm{F}$ & $2132.05^{*}$ & $2239.23^{*}$ & & & & & & & & & $736.75^{*}$ & $2458.70^{*}$ \\
\hline & & $\mathrm{LSD}_{05}$ & 0.01 & 0.01 & & & & & & & & & 0.00 & 0.02 \\
\hline \multirow{5}{*}{\multicolumn{2}{|c|}{$\begin{array}{c}\text { (C) } \\
\text { Supper } \\
\text { Phosphate }\end{array}$}} & 0 & 7.69 & 2.53 & 8.32 & 7.29 & 9.45 & 0.28 & 0.00 & 4.92 & 12.01 & 8.42 & 0.09 & 3.38 \\
\hline & & 50 & 7.68 & 2.56 & 8.39 & 7.36 & 9.67 & 0.29 & 0.00 & 4.72 & 12.36 & 8. & 0.10 & 3.44 \\
\hline & & 75 & 7.67 & 2.60 & 8.48 & 7.41 & 9.89 & 0.29 & 0.00 & $4.5 \overline{7}$ & 12.84 & 8.67 & 0.11 & 3.50 \\
\hline & & 100 & 7.66 & 2.65 & 8.60 & 7.46 & 10.15 & 0.30 & 0.00 & 4.35 & $\begin{array}{l}13.21 \\
\end{array}$ & 8.95 & 0.13 & 3.58 \\
\hline & & $F$ & NS & $21.75^{*}$ & & & & & & & & & $233.97^{*}$ & $\frac{34.27^{*}}{0.04}$ \\
\hline
\end{tabular}


Table (12): Effect of different treatments on maize yield and its components in the first season.

\begin{tabular}{|c|c|c|c|c|c|c|c|c|c|c|c|}
\hline $\begin{array}{l}\text { Spraying } \\
\text { ascobin }\end{array}$ & $\begin{array}{l}\text { Irrigation } \\
\text { intervals }\end{array}$ & $\begin{array}{l}{ }^{*} \text { Super- } \\
\text { phosphate }\end{array}$ & $\begin{array}{c}\text { Plant } \\
\text { height, } \\
\text { cm }\end{array}$ & $\begin{array}{c}\text { Ear } \\
\text { length, } \\
\text { cm }\end{array}$ & $\begin{array}{c}\text { Ear } \\
\text { diameter, } \\
\text { cm }\end{array}$ & $\begin{array}{c}\text { No. of } \\
\text { rows per } \\
\text { ear }\end{array}$ & $\begin{array}{l}\text { No. of } \\
\text { kernels } \\
\text { per row }\end{array}$ & $\begin{array}{l}100 \text { seed } \\
\text { weight, g }\end{array}$ & $\begin{array}{c}\text { Grain yield, } \\
\text { ton/fed }\end{array}$ & R.I.G.Y., \% & $\begin{array}{c}\text { Dry matter, } \\
\text { g/plant after } 80 \\
\text { days }\end{array}$ \\
\hline \multirow{12}{*}{ without } & \multirow{4}{*}{1 week } & 0 & 272.38 & 21.27 & 15.64 & 15.27 & 45.31 & 32.90 & 2.2522 & -1.28 & 207.61 \\
\hline & & 50 & 274.29 & 21.45 & 15.84 & 15.41 & 46.15 & 33.19 & 2.2689 & -0.54 & 210.43 \\
\hline & & 75 & 277.44 & 21.72 & 16.02 & 15.78 & 47.07 & 33.52 & 2.2775 & -0.17 & 213.83 \\
\hline & & 100 & 279.02 & 21.92 & 16.14 & 16.08 & 48.35 & 33.86 & 2.2846 & 0.14 & 218.98 \\
\hline & \multirow{4}{*}{2 weeks } & 0 & 276.27 & 21.49 & 15.73 & 15.36 & 46.16 & 33.37 & 2.2813 & 0.00 & 213.79 \\
\hline & & 50 & 279.24 & 21.69 & 15.75 & 15.47 & 46.75 & 34.05 & 2.3511 & 3.06 & 222.66 \\
\hline & & 75 & 281.36 & 21.79 & 15.80 & 15.66 & 47.29 & 34.41 & 2.4311 & 6.57 & 228.74 \\
\hline & & 100 & 283.78 & 21.93 & 15.92 & 15.71 & 47.80 & 34.72 & 2.5076 & 9.92 & 231.21 \\
\hline & \multirow{4}{*}{3 weeks } & 0 & 269.09 & 20.75 & 15.28 & 14.97 & 44.02 & 32.68 & 2.2200 & -2.69 & 198.54 \\
\hline & & 50 & 272.06 & 21.11 & 15.48 & 15.11 & 44.52 & 32.89 & 2.2316 & -2.18 & 205.39 \\
\hline & & 75 & 276.32 & 21.29 & 15.78 & 15.53 & 44.66 & 33.18 & 2.2428 & -1.69 & 213.08 \\
\hline & & 100 & 279.70 & 21.89 & 16.08 & 15.97 & 46.18 & 33.53 & 2.2554 & -1.14 & 227.13 \\
\hline \multirow{12}{*}{ with } & \multirow{4}{*}{1 week } & 0 & 292.30 & 22.78 & 16.33 & 16.43 & 49.79 & 36.20 & 2.6142 & 14.59 & 256.43 \\
\hline & & 50 & 294.60 & 22.91 & 16.34 & 16.65 & 50.11 & 36.36 & 2.6627 & 16.72 & 259.85 \\
\hline & & 75 & 297.00 & 23.19 & 16.55 & 16.78 & 51.33 & 36.62 & 2.7248 & 19.44 & 264.70 \\
\hline & & 100 & 298.92 & 23.24 & 16.60 & 16.85 & 51.75 & 36.91 & 2.8484 & 24.86 & 268.87 \\
\hline & \multirow{4}{*}{2 weeks } & 0 & 300.58 & 23.41 & 16.71 & 16.98 & 52.07 & 37.26 & 2.9854 & 30.86 & 273.58 \\
\hline & & 50 & 305.41 & 23.57 & 16.78 & 17.08 & 52.65 & 37.71 & 3.1084 & 36.26 & 285.41 \\
\hline & & 75 & 306.07 & 23.98 & 16.80 & 17.35 & 53.07 & 38.05 & 3.1678 & 38.86 & 292.29 \\
\hline & & 100 & 310.51 & 24.60 & 17.08 & 17.74 & 53.71 & 38.76 & 3.2077 & 40.61 & 299.25 \\
\hline & \multirow{4}{*}{3 weeks } & 0 & 284.73 & 22.07 & 15.94 & 15.77 & 48.10 & 35.26 & 2.5197 & 10.45 & 233.96 \\
\hline & & 50 & 286.14 & 22.27 & 16.02 & 15.98 & 48.69 & 35.47 & 2.5235 & 10.62 & 241.76 \\
\hline & & 75 & 287.37 & 22.48 & 16.03 & 16.01 & 49.27 & 35.81 & 2.5586 & 12.16 & 244.30 \\
\hline & & 100 & 289.96 & 22.68 & 16.28 & 16.32 & 49.52 & 35.95 & 2.5939 & 13.70 & 249.35 \\
\hline \multicolumn{3}{|c|}{ Control } & 276.27 & 21.49 & 15.73 & 15.36 & 46.16 & 33.37 & 2.2813 & 0.00 & 213.79 \\
\hline \multirow{4}{*}{\multicolumn{2}{|c|}{$\begin{array}{c}\text { (A) } \\
\text { Spraying } \\
\text { ascobin }\end{array}$}} & Without & 276.75 & 21.53 & 15.79 & 15.53 & 46.19 & 33.53 & 2.3003 & 0.83 & 215.95 \\
\hline & & with & 296.13 & 23.10 & 16.46 & 16.66 & 50.84 & 36.70 & 2.7929 & 22.43 & 264.15 \\
\hline & & $\mathrm{F}$ & $581.40^{*}$ & $576.95^{*}$ & $616.62^{*}$ & $574.83^{*}$ & $576.89^{*}$ & $580.58^{*}$ & $585.5952^{*}$ & $586.77^{\star}$ & $583.12^{*}$ \\
\hline & & $\mathrm{LSD}_{05}$ & 3.46 & 0.28 & 0.12 & 0.20 & 0.83 & 0.57 & 0.0876 & 3.84 & 8.59 \\
\hline \multirow{5}{*}{\multicolumn{2}{|c|}{$\begin{array}{l}\text { (B) } \\
\text { Irrigation } \\
\text { intervals }\end{array}$}} & 1 week & 285.74 & 22.31 & 16.18 & 16.16 & 48.73 & 34.95 & 2.4917 & 9.22 & 237.59 \\
\hline & & 2 weeks & 292.90 & 22.81 & 16.32 & 16.42 & 49.94 & 36.04 & 2.7551 & 20.77 & 255.87 \\
\hline & & 3 weeks & 280.67 & 21.82 & 15.86 & 15.71 & 46.87 & 34.35 & 2.3932 & 4.90 & 226.69 \\
\hline & & $\mathrm{F}$ & $928.88^{*}$ & $892.88^{*}$ & $750.64^{*}$ & $726.23^{*}$ & $1037.19^{*}$ & $1061.97^{*}$ & $894.2667^{*}$ & $893.91^{*}$ & $904.40^{*}$ \\
\hline & & $\mathrm{LSD}_{05}$ & 0.66 & 0.05 & 0.03 & 0.04 & 0.16 & 0.09 & 0.0205 & 0.89 & 1.60 \\
\hline \multirow{6}{*}{\multicolumn{2}{|c|}{$\begin{array}{l}\text { (C) } \\
\text { Supper }\end{array}$}} & 0 & 282.56 & 21.96 & 15.94 & 15.80 & 47.58 & 34.61 & 2.4788 & 8.66 & 230.65 \\
\hline & & 50 & 285.29 & 22.17 & 16.04 & 15.95 & 48.15 & 34.95 & 2.5244 & 10.65 & 237.58 \\
\hline & & 75 & 287.59 & 22.41 & 16.16 & 16.19 & 48.78 & 35.27 & 2.5671 & 12.53 & 242.82 \\
\hline & & 100 & 290.32 & 22.71 & 16.35 & 16.45 & 49.55 & 35.62 & 2.6163 & 14.68 & 249.13 \\
\hline & & $\mathrm{F}$ & $17.65^{*}$ & $28.11^{*}$ & $15.96^{*}$ & $41.47^{*}$ & $41.23^{*}$ & $20.23^{*}$ & $72.0415^{*}$ & $1731.24^{*}$ & $147.97^{*}$ \\
\hline & & $\mathrm{LSD}_{05}$ & 2.26 & 0.17 & 0.13 & 0.13 & 0.38 & 0.28 & 0.0198 & 0.18 & 1.85 \\
\hline
\end{tabular}

* $\%$ of recommended dose 